\title{
Shared traditions and shard conservatism: pottery making at the Chalcolithic site of Radovanu (Romania)
}

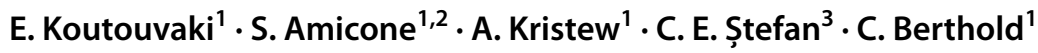

Received: 13 December 2020 / Accepted: 15 July 2021 / Published online: 28 October 2021

(c) The Author(s) 2021

\begin{abstract}
This work investigates the technology of pottery production at the Chalcolithic site of Radovanu-La Muscalu (first half of the fifth millennium BCE), in southern Romania. The excavation of this settlement yielded a rich and well-contextualised archaeological assemblage that represents the last phases of development of Boian material culture, a Chalcolithic phenomenon that spread throughout the lower Danube area at the end of the sixth millennium BCE and the first half of fifth millennium BCE. To carry out this investigation, a total of forty-nine ceramic samples, representative of the different pottery types and chronological horizons attested at this site, together with geological samples collected around Radovanu, were selected. These were analysed using a multi-pronged scientific approach including ceramic petrography, X-ray diffraction, and scanning electron microscopy. This interdisciplinary study elucidates different aspects of the local pottery production and indicates that ceramics at Radovanu were manufactured according to a conservative tradition that consistently made use of grog tempering throughout all phases in which this settlement was inhabited. The results also show that at Radovanu, regional technological traits coexisted with elements that were widely applied in the Balkan region at that time, such as graphite-painted decoration. This investigation together with the identification of potential non-local productions well illustrates the complex interrelationships between the Boian phenomenon and the neighbouring material cultures in the Balkans.
\end{abstract}

Keywords Pottery $\cdot$ Ancient technology $\cdot$ Chalcolithic Balkans $\cdot$ Material cultures $\cdot$ Grog $\cdot$ Archaeometry

\section{Introduction}

The Late Neolithic and Chalcolithic period of Southeastern Europe (sixth to fourth millennium BCE) is marked by the establishment and development of a fully sedentary system and the formation of various material cultures (e.g. Childe 1957: 84-104; Bailey 2000, 2005: 1-10; Borić 2015). The Boian phenomenon (5200-4550 cal. BCE) in the lower Danube area was part of this complex mosaic of Neolithic and Chalcolithic cultures characterised by an advanced pottery technology well

E. Koutouvaki

eirini.koutouvaki@student.uni-tuebingen.de

S. Amicone

silvia.amicone@uni-tuebingen.de

1 Competence Center Archaeometry - Baden-Wuerttemberg, Eberhard Karls Universität, Tübingen, Germany

2 Institute of Archaeology, University College London, London, UK

3 Institutul de Arheologie Vasile Pârvan, Bucharest, Romania displayed by the use of various decorative techniques (e.g. Yiouni 2000; Bonga 2013). Boian phenomenon is traditionally divided in four sub-phases: Bolintineanu, Giulești, Vidra, and Spanțov (Table 1, Comşa 1974), respectively, listed earlier to later. These phases have been the object of different studies, mostly focusing on ceramic chrono-typological classification (e.g. Comşa 1974). The importance of a technological approach to the study of pottery has often been emphasised in the anthropological and archaeological literature (e.g. van der Leeuw 1989, 1993; Costin 1991; Lemonnier 1992; 1993; Dobres and Hoffmann 1994). Recent studies focused on the Balkans show how this region became a living laboratory for technological investigations into pottery manufacture (Kreiter 2010; Kreiter et al. 2017a, b; Spataro 2017; 2018; Amicone 2019; Spataro et al 2019). As encouraging as these developments are, there is limited knowledge on Boian pottery, particularly its manufacturing technology (Micu 1999; Thissen 2014; Opris and Ştefan 2016; Opriş et al. 2017; Opriş et al. 2019; Ştefan 2019).

To fill this gap in our knowledge, the present work aims to investigate pottery manufacturing technology at the 
Table 1 List of chronological phases represented at Radovanu

\begin{tabular}{llll}
\hline Phase & & Absolute chronology & Radovanu stratigraphy \\
Bolintineanu & I & $5200-5100 \mathrm{BC}$ & - \\
Giuleşti & II & $5100-5000 \mathrm{BC}$ & - \\
Vidra & III & $5000-4800 \mathrm{BC}$ & Layer 5 \\
Spanţov & IV & $4900-4550 \mathrm{BC}$ & Layers 4, 3, 2, 1 \\
\hline
\end{tabular}

site of Radovanu-La Muscalu (henceforward Radovanu) in southern Romania (Fig. 1) through an interdisciplinary approach. Excavated by Eugen Comșa between 1960 and 1990 (Comșa 1990), this site provided a large amount of well-contextualised pottery from different dwelling phases (Table 2) spanning the last development of the Boian material culture (Vidra and Spanțov phases). Additionally, these well-contextualised pottery sherds co-occur with evidence of pottery manufacturing (e.g. pyrotechnological installations).

Preliminary studies carried out by Comşa (1990: 120-121) and later by Ştefan (2019) on the ceramics from Radovanu emphasised the potential of applying a technological approach to understand various aspects of organisation and production at this site. In the present study, by analysing a representative selection of ceramic sherds from the various archaeological horizons attested at Radovanu, it was possible to carry out a more systematic technological characterisation of the ceramic production at this site and explore the connections of this community with the neighbouring and/or distant areas. This investigation represents a significant contribution to the study of Boian phenomenon with an approach that helps to explore not only social aspects connected to pottery manufacturing within this material culture, but also the sharing of technological traditions across the ancient Balkans.

\section{Archaeological background}

The site of Radovanu is located approximately $1.5 \mathrm{~km}$ from the modern village of Radovanu, at Călărași county in southern Romania. It was first discovered in 1959 by B. Ionescu, former director of Olteniţa Museum History. One year later, Eugen Comșa began the excavations at the site, which lasted until 1990 (Comșa 1990: 8-12).

The excavations revealed four main sections (Fig. 2): the main settlement (acropolis), the necropolis, an open area of settlement, and a weaving workshop (Comșa 1990: 12-17). According to the stratigraphy of the site defined by Comșa, five archaeological horizons were recognised within the main settlement area (Fig. 2A). The oldest, level 5, belongs to the Boian-Vidra phase. This level represents a short-term habitation horizon, which is mostly attested at the eastern part of the site. The other four layers of dwelling units (levels 4-1) are dated to the Boian-Spanțov (Comșa 1990: 12-17).
Three radiocarbon dates confirm the chronological timespan of the Spanţov phase, around 4900-4550/4525 BCE (Bem 2000-2001; Voinea and Neagu 2008: 16; Ștefan 2014a: 157; Ștefan 2019: 142).

A large amount of well-contextualised pottery, most of which is currently under study, was found in the dwellings of the main settlement and dated to the last phase of the Boian culture (Spantov phase), while the Vidra phase is also represented, but to a lesser extent. Among the thousands of sherds, there are also nine pottery fragments that show stylistic characteristics typical of neighbouring contemporaneous material cultures (Hamagia, Vinča, and Precucuteni) and have been interpreted as a possible import to the site (Comșa 1990: 62, 115; Ştefan 2019).

Comșa also reported the discovery of a possible pit firing installation of $2 \mathrm{~m}$ diameter and $1 \mathrm{~m}$ depth. The colour of the walls of this pit indicated a thermal alteration, and carbonised acorns were found within it, suggesting the use of oak as fuel (Comșa 1990: 66; Ştefan 2019: 150). Finally, in some dwellings of level $1(1,7$, and 11), Comşa discovered five clay lumps that were likely made by the potters at the beginning of the manufacturing process (Comșa 1990: 65). These are not commonly preserved in the archaeological record as they are made of unfired clay. A conflagration event is responsible for the preservation of these clay lumps from Radovanu, thus providing information on the typical paste used by the potters at this site. The hand specimen analysis (Ştefan 2019) of these lumps suggests the presence of grog (crushed ceramic sherds), thus supporting the preliminary archaeometric observation of pottery samples (Comşa 1990: 120-121; Ştefan 2019). Unfortunately, due the rarity of these finds, it is not possible to carry out destructive analysis, such as ceramic petrography, on these artefacts.

\section{Geological background}

The site of Radovanu (Fig. 1) is located approximately $40 \mathrm{~km}$ south of Bucharest and about $13 \mathrm{~km}$ north of the Danube in an area marked by the presence of gentle hills. The site is situated above a Neogene sedimentary basin (Fig. 3) that developed in the central part of the Moesic platfrom (Petrescu and Mitroi 1965; Ciugudean-Toma and Stefanescu 2006). After a long period of erosion during the Paleogene, subsidence in Miocene times led to the accumulation of deep-water deposits of clay and clayey marl within the Sarmatian Sea. During the Pliocene, as the connection to the Sarmatian Sea was periodically interrupted, shallower water facies, composed predominantly of sand and gravel, accumulated. By the end of the Pliocene, the basin infilling was complete, providing a landscape for Quaternary development of the Romanian plains. The Quaternary sequence of $250 \mathrm{~m}$ in thickness comprises fluvial, lacustrine, and windblown deposits (loess). Nowadays, the area where Radovanu 

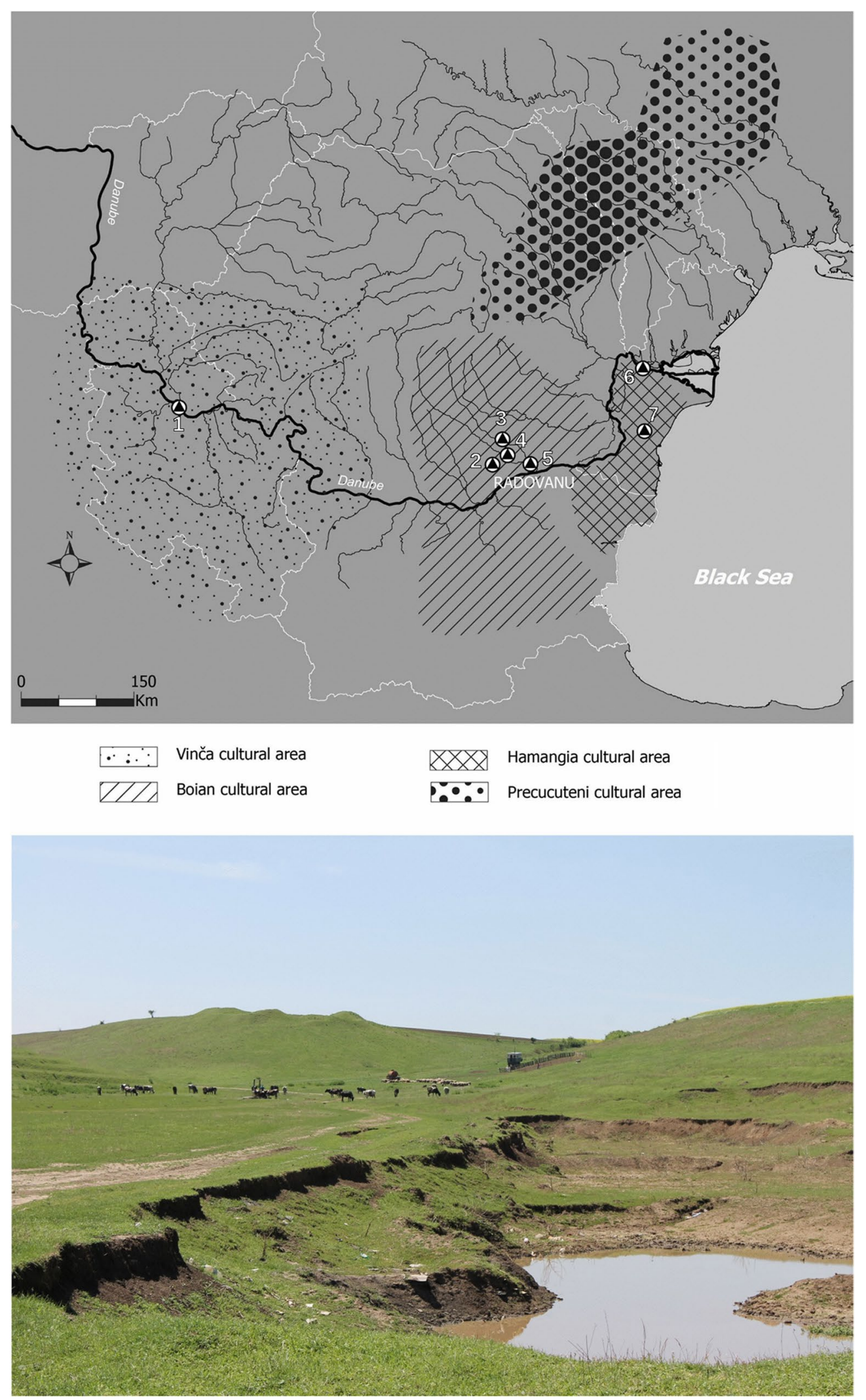

Fig. 1 (Above) Distribution of the material cultures and archaeological sites mentioned in this study: 1 Vinča-Belo Brdo, 2 Tangaru (Stoenești, jud. Giurgiu), 3 București-Giulești, 4 Vidra, 5 RadovanuLa Muscalu, 6 Isaccea-Suhat, 7 Cheia (created by M. Florea after
Marinescu-Bîlcu 1974, 213, Fig. 2, Hașotti 1997, Fig. 4, Comșa 1974, Fig. 9-12, Chapman 1981, Map A); (below) picture of the site of Radovanu 


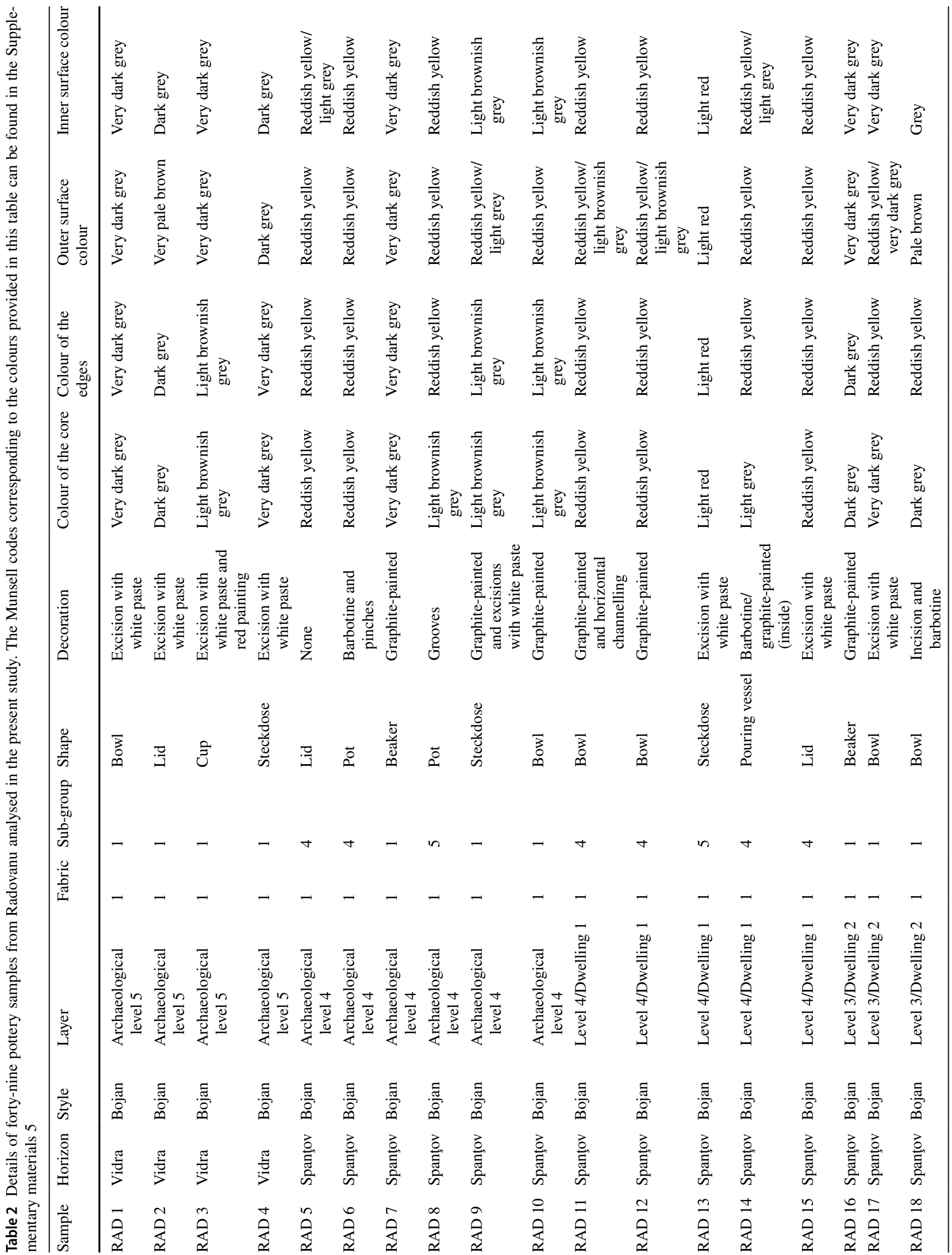




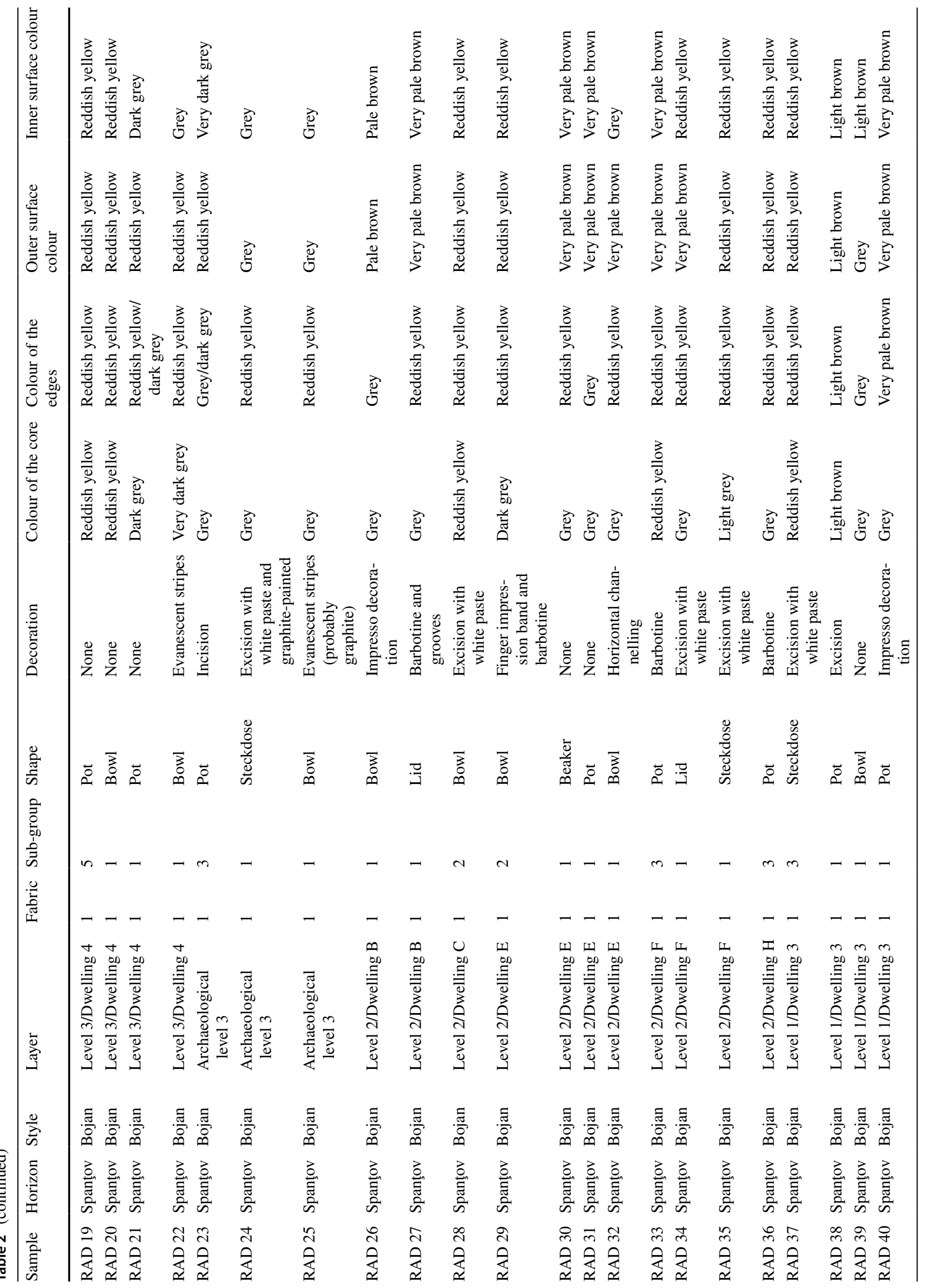




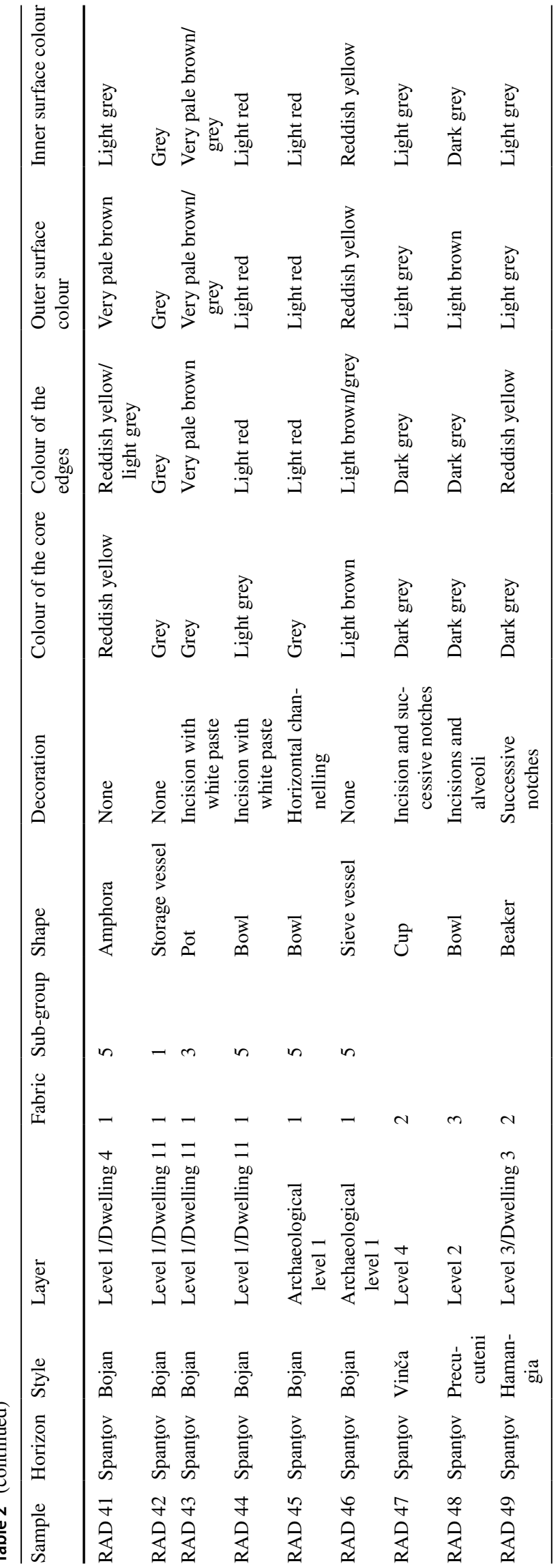

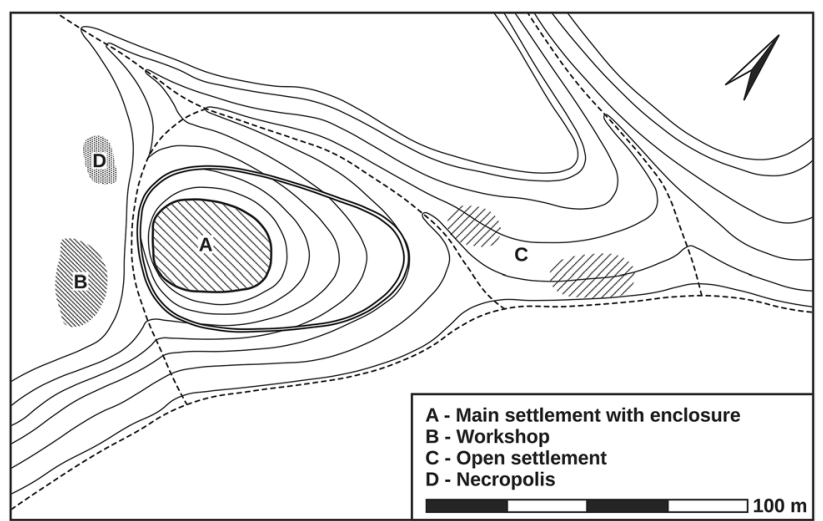

Fig. 2 Map of the site of Radovanu (after Comşa 1990, Fig. 29, created by L. Heinze). A Main settlement with enclosure. B Workshop. C Open settlement. D Necropolis

lies is marked by the presence of Quaternary sediments rich in clays, sands, gravels, marls, and loess deposits.

\section{Materials and methods}

Forty-nine pottery sherds from the Radovanu assemblage were collected to be studied through an interdisciplinary approach. They represent all the five archaeological layers discovered at the site with consideration of the different types of pots in terms of functional form and decoration (Table 2 and Supplementary materials 1). These also include three of the nine sherds marked by characteristics that are not referable to Boian material culture (Hamangia, Vinča, and Precucuteni). Unfortunately, it was possible to get the permission to analyse only one example from each material culture.

To gain insight on firing atmosphere, the samples were first studied macroscopically by recording colour variability of the surface and of the cross sections within the individual sherds (Rice 2015: 276-290; Mentesana et al. 2017; Amicone et al. 2020a). In addition, forming and finishing techniques were studied by examining macro-traces left by the potters (Roux 2017).

The samples were then prepared as thin sections. A slice from the vertical cross-section of each sherd was removed and pasted over a glass slide and then ground to approximately $30 \mu \mathrm{m}$ thickness and subsequently studied under a polarising microscope to identify the compositional and technological characteristics of the materials under investigation (Whitbread 1989; Quinn 2013: 23-33).

In addition, eight samples belonging to fabric 1 (which was the most frequently attested fabric in the assemblage) were studied via X-ray powder diffraction (XRPD) for more detailed investigation of mineral phases that could not be identified by petrographic analysis due to the small 


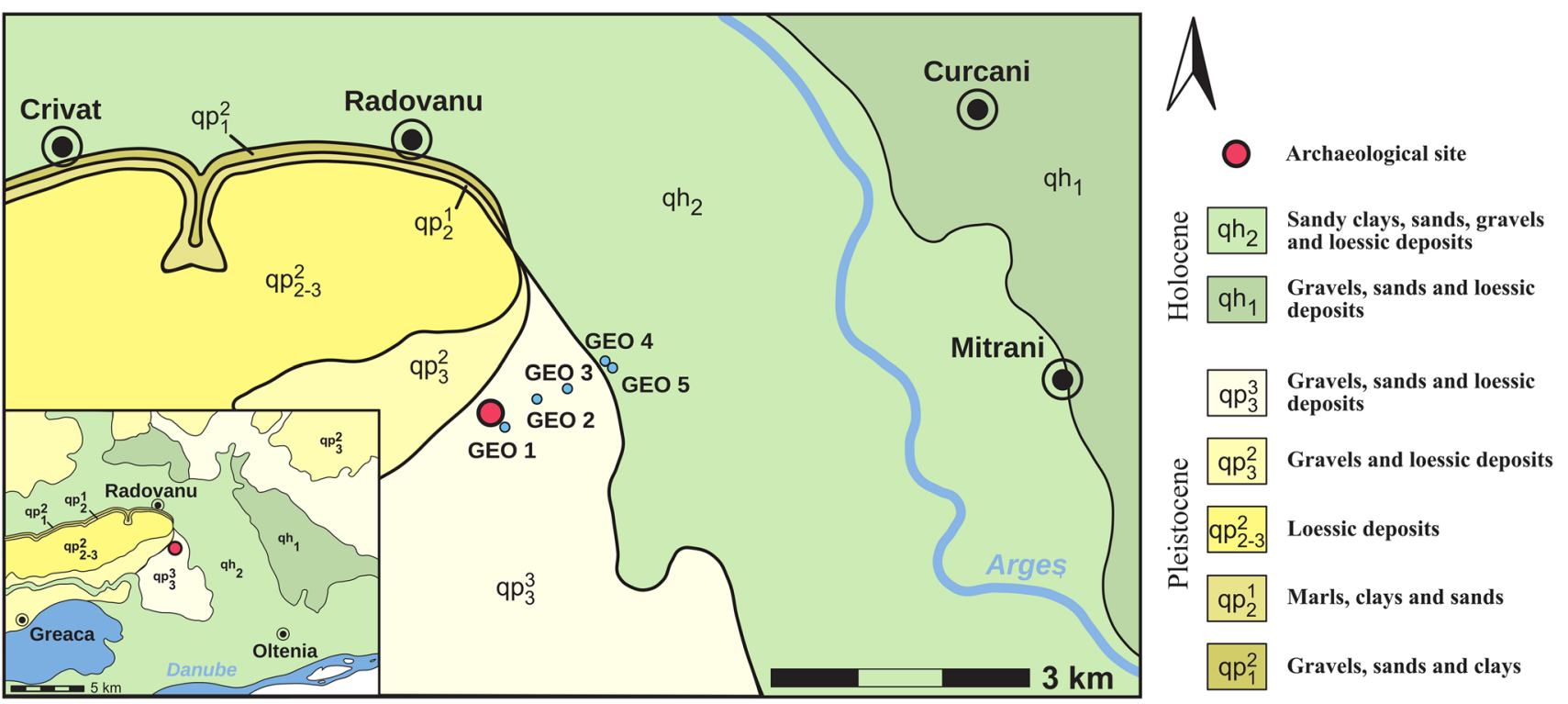

Fig. 3 Simplified geological map of the area around Radovanu (created by L. Heinze after Petrescu and Mitroi 1965)

crystalline size, such as clay minerals. During the firing process of pottery, mineral phases form or disappear under specific temperatures and atmospheric conditions. Therefore, the absence/presence of certain minerals can be informative about temperature and the firing conditions at which pottery was exposed (Maggetti 1982; Maritan 2004; Maritan et al. 2007; Nodari et al. 2007; Amicone et al. 2020a; Gliozzo 2020).

The surface of the sample was removed using a drill, and each specimen was ground with an agate mortar and pestle. For the measurements, a Bruker D8 advance diffractometer with a $\mathrm{Cu}$-sealed tube running at $40 \mathrm{kV} / 20 \mathrm{~mA}$, a Göbel mirror parallel beam optics, a 0.2-mm divergence slit, a fixed knife edge to suppress air scatter, sample rotation, and a 1D-VÁNTEC 1-detector in scanning mode was used. Typical measurement time was $405 \mathrm{~s} / \mathrm{step}$ with a step size of $0.008^{\circ} 2 \theta$. The mineral identification was performed using the 2006 PDF-4 database from the International Centre for Diffraction Data-Joint Committee of Power Diffraction Standards (ICDD-JCPDS).

Additionally, the same eight samples mentioned above have been studied under scanning electron microscope (SEM) using the secondary electron detector. The fresh fracture of these samples was platinum coated, and the analysis was carried out via a Hitachi TM3030 + using an accelerating voltage of $15 \mathrm{kV}$, an operating current of $110 \mu \mathrm{A}$, and a variable working distance at $1000 \times$ and $2000 \times$ magnifications. This method informs about the microstructure of the sample, namely, the degree of vitrification, which is also a crucial point in pyrotechnological studies (Tite and Maniatis 1975a, b; Maniatis and Tite 1975, 1981; Faber et al. 2009).
Five geological samples were collected in the Quaternary deposits east from Radovanu (Fig. 3), the only area where we were allowed to carry out the prospections. All geological specimens were taken from visible surface outcrops found during our survey for raw materials (Fig. 4 and Supplementary materials 2). Among them, four are sandy clays and one is a sand sample. These specimens were all analysed via petrography, and the sandy clay samples were also measured via XRPD with the same instrument and parameters used for the ceramic samples. The thin sections for the petrographic analysis of the clay samples were prepared from briquettes obtained by mixing $20 \mathrm{~g}$ of clay with de-ionised water. These briquettes were fired in oxidising conditions in a furnace (Nabertherm P 300) at $500{ }^{\circ} \mathrm{C}(2 \mathrm{~h}$ to reach the maximum temperature, $1 \mathrm{~h}$ at maximum temperature, $2 \mathrm{~h}$ of cooling). The clay samples for XRPD analysis were not fired.

\section{Macroscopic observations of the archaeological samples}

The forty-nine pottery sherds from the Radovanu selected for this study include forty-six samples displaying characteristics typical of the Boian culture (Vidra and Spanţov phases), while three samples show stylistic traits referable to other material cultures (Hamangia, Vinča, and Precucuteni).

Regarding the first group of sherds, the shapes recognised include jars, different types of bowls, pedestal bowls (also called steckdosen), pouring vessels, lids, cups, storage (so-called amphorae), and sieving vessels. Their fabric is 
Fig. 4 Pictures showing the outcrops where the geological samples were collected: a GEO 1 , very fine sandy clay; $\mathbf{b}$ GEO

2 , very fine sandy clay; $\mathbf{c}$ GEO

3 , medium fine sandy clay; $\mathbf{d}$

GEO 4, medium fine sandy clay; e GEO 5, coarse sand (created by S. Amicone)
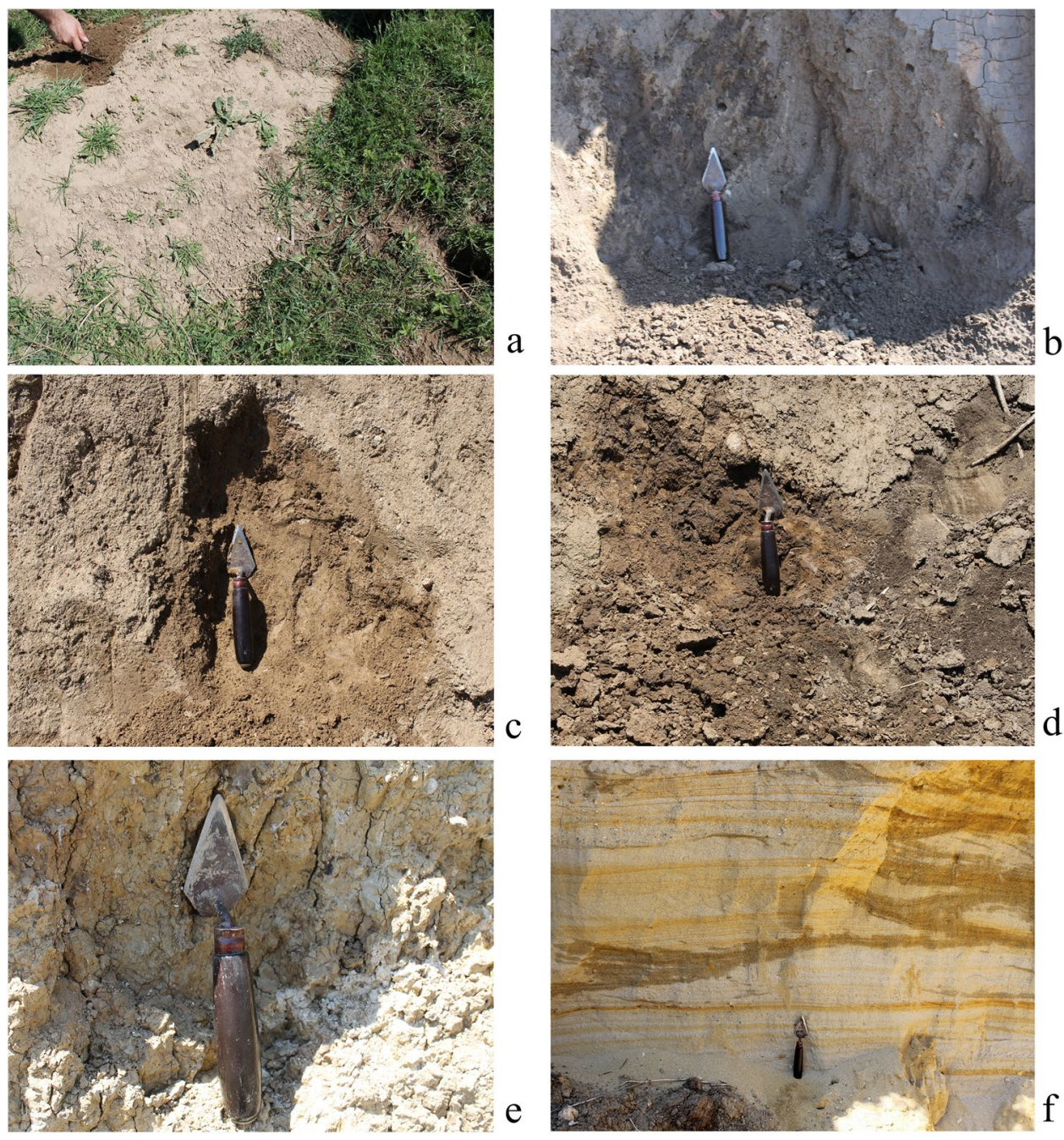

relatively hard, fine to coarse in texture, and marked by the presence of white, black, and more rarely shining inclusions (Table 2 and Supplementary materials 1).

Most of the pots show a pale yellow to reddish yellow surface and fabric colour that indicates firing under oxidising conditions (Table 2, Fig. 5f). Some sherds (e.g. RAD 22 , RAD 26, RAD 40) are marked by a fabric with a grey core and pale yellow to reddish yellow edges (Fig. 5d, g). This could indicate a relatively fast firing process that does not allow for the complete combustion of the organic matter present in the clay paste (Rice 2015: 279-280). Few samples show bright reddish or orange surface colour and sometimes slightly darker core (e.g. RAD 13, RAD 19, RAD 44, RAD 45, Fig. 5h). Finally, some specimens have a light grey (Fig. 5a-c) or reddish core and darker grey to very dark grey/black edges (Fig. 5e). This could suggest firing under reducing conditions in a two-step procedure of oxidation-reduction (Amicone et al. 2020a) where reducing conditions were not always well-controlled as is indicated by the non-homogenous colour of these specimens.
The study of the macro-traces left by the potters indicates that the primary forming technique in Radovanu was coiling. Macro-traces indicative of this technique include points of connections between adjacent coils and the presence of preferential fractures that follow these areas between coils (e.g. RAD 39, 44). Another typical feature indicative for coiling is the variable thickness of the walls of the pots (Rye 1981: 67-68; Rice 1987: 127-128; Roux 2017: 200-206). After being formed, the surface of the vessel was finished via smoothing and/or burnishing (Martineau 2010), though it has been observed in some cases that a slip could have been applied to the surface of the vessel (Supplementary materials 1 ).

Most of the samples are decorated with various techniques (Fig. 6) that are quite common in Neolithic/Chalcolithic sites from the Balkans (Mirea 2009: 284, 287; Bonga 2013: 260-263; Thissen 2013: 48, 58). The most frequently attested are incisions (Fig. 6d) and excisions filled with white pigment (Fig. 6a). The latter is the only decorative technique attested in the Vidra phase. Both 
Fig. 5 Selected sherds from Radovanu seen in fresh fracture: a RAD 1; b RAD; c RAD 7; d RAD 22; e RAD 24; f RAD 36; g RAD 40; h RAD 44 (created by $\mathrm{S}$. Amicone)
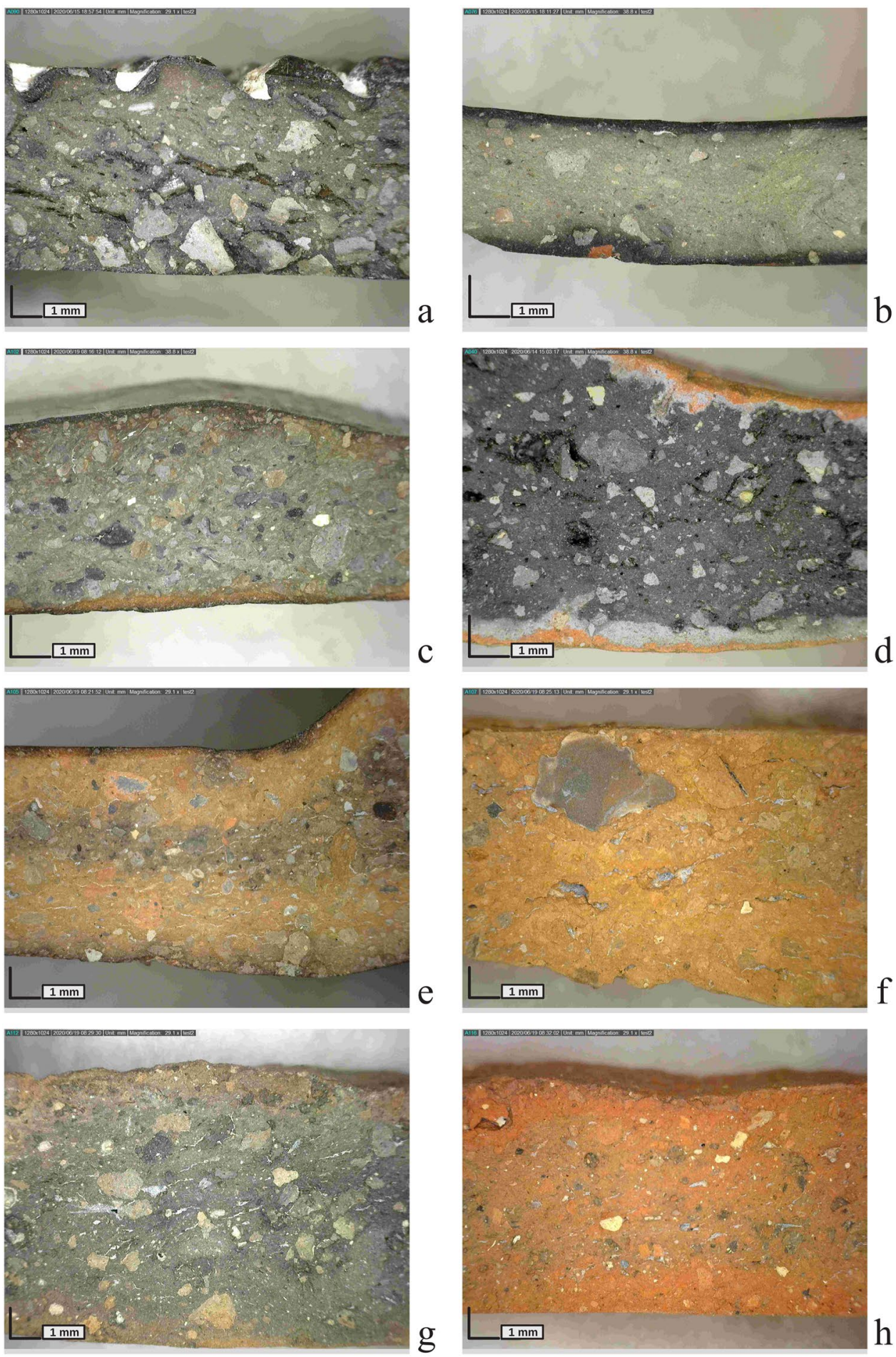

$\mathrm{g}$

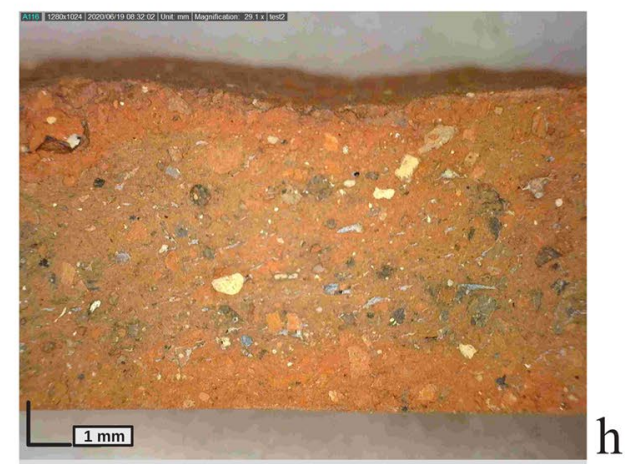

incisions and excisions are performed when the unfired pottery paste is still soft. Incisions are obtained through a displacement of clay, while excisions are achieved by carving the unfired pottery paste and therefore by removing clay from the pot's surface (Roux 2017). In the Vidra phase (layer 5), excisions are applied over large areas of the vessels (Fig. 6a), while in Spanţov, phase narrow channels are preferred (Fig. 6b). Recent analysis indicated that this white paste could be slaked (hydrated) lime applied after the firing process (Perišić et al. 2016; Ștefan 2019).

Other decorative techniques include impresso (Fig. 6e) and barbotine (Fig. 6d). The term barbotine refers to the technique where the potter applies an uneven layer of clay before firing the vessel, which gives an intentional roughness 
Fig. 6 Pottery from Radovanu showing various decoration techniques: a RAD 1, excision with white paste; b RAD 24, excision with white paste and graphite-painted; c RAD 10, graphite-painted; d RAD 18, incision and barbotine; e RAD 26, impresso; f RAD 3, excision with white paste and red painting (created by E. Koutouvaki)

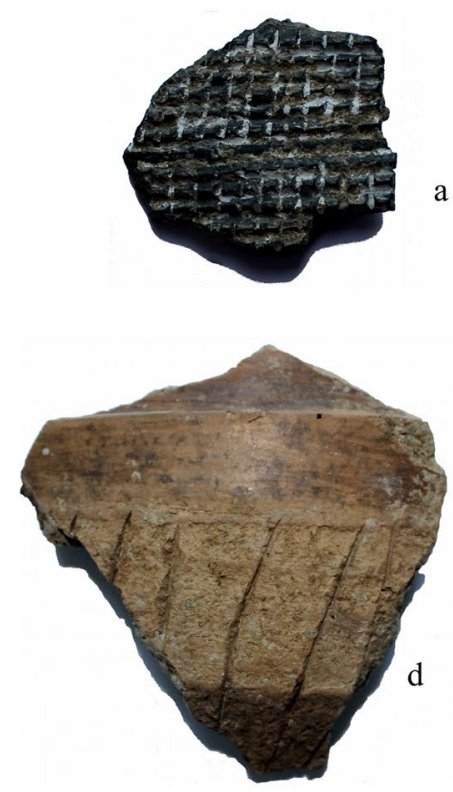

on the surface of the pot (Vuković 2013: 661-664; Stojanovski et al. 2014: 12, 16, 20-21).

Painting with red pigments (Fig. 6f) and graphite (Fig. 6b-c) are additional decoration techniques observed in Radovanu assemblage. Graphite painting became very popular for about 1000 years throughout the Balkans in the fifth millennium BCE (e.g. Todorova 1995; Bailey 2000: 224-229; Leshtakov 2005; Martinon 2017; Amicone et al. 2020a). Graphite is a crystalline form of carbon which can be found in metamorphic rocks (marble, schist, gneiss) as well as in some igneous rocks. After being mixed with water and clay, it was applied to a burnished surface and would have been fixed to the vessel surface through firing under predominately reducing conditions (Kreiter et al. 2014; Amicone et al. 2020a and literature therein). In Radovanu, graphite painting is attested from layer 4 (Spanţov phase) in association with bowls, beakers, and pedestal bowls marked by fine fabrics and thin walls. The graphite was normally applied on the external surface, but sometimes decoration can be observed on the inner surface (e.g. RAD 14). Graphite-painted decoration is found in Radovanu in association with horizontal channelling (e.g. RAD 10) or excised decoration filled with white paste (e.g. RAD 24).

Finally, among the samples selected, as mentioned above, three sherds stand out for their decorative characteristics (Table 2) that connect them to the Hamangia (Fig. 7a), Vinča (Fig. 7b), and Precucuteni (Fig. 7c) material cultures. They are all made by using coiling technique and their surfaces

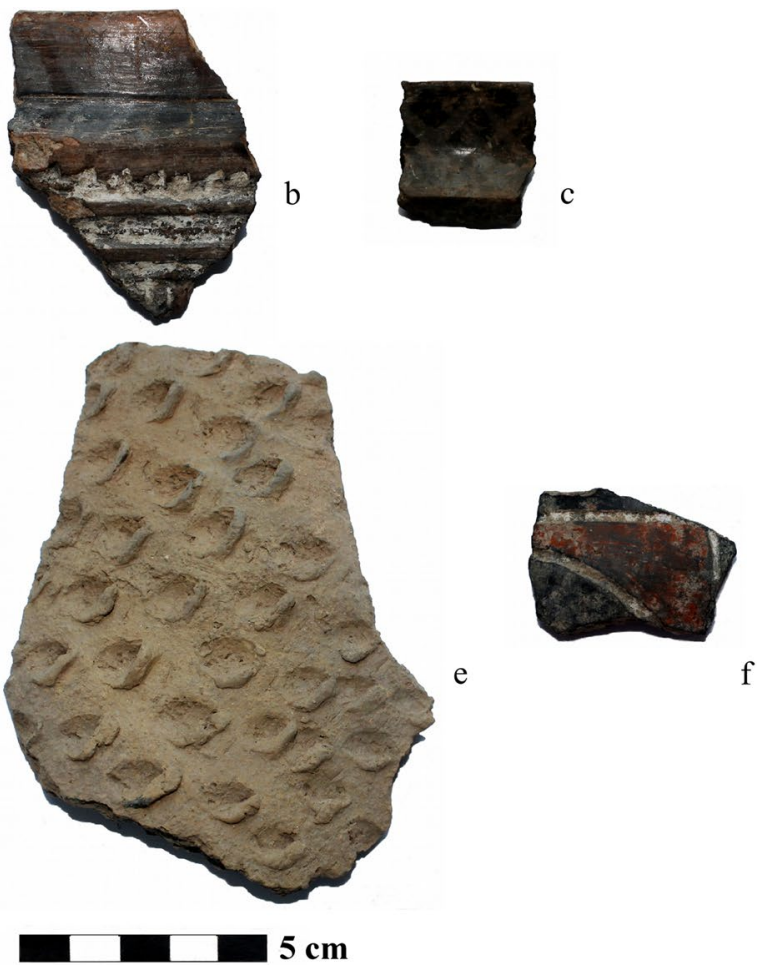

were burnished before being decorated. From the observation of their fabric and surface colour, it appears that the Vinča fragment was fired under reducing conditions while the others under more variable firing atmospheres.

\section{Results of the scientific analysis}

\section{Geological samples}

\section{Petrographic analysis}

GEO 1 is a non-calcareous sandy clay sample where the average size of inclusions is $0.1 \mathrm{~mm}$ (very fine sand) and their abundance ranges around $40 \%$ (Fig. 8a). The dominant type of inclusion is quartz. Muscovite is frequent, while biotite, feldspars (plagioclase), and micrite are common. The texture and composition of GEO 2 are similar to GEO 1 (Fig. 8b), but micrite occurs more rarely in GEO 2.

GEO 3 is a coarse non-calcareous sandy clay where the average size of inclusions is $0.30 \mathrm{~mm}$ (medium fine sand) and their abundance ranges around 30\% (Fig. 8c). The dominant type of inclusion is quartz, and micrite and muscovite occur frequently, while plagioclases and biotite appear commonly. Rare fragments of foliated metamorphic rocks composed of quartz were also detected. Very rarely fragments of shells are observed in the samples. GEO 4 has a similar texture and 
Fig. 7 Pottery from Radovanu marked by non-local decorative motives: a RAD 49 showing successive notches, Hamangia material culture; b RAD 47 showing incision and successive notches, Vinča material culture; c RAD 48 showing incisions and alveoli, Precucuteni material culture (created by C. E. Ștefan and E. Koutouvaki)
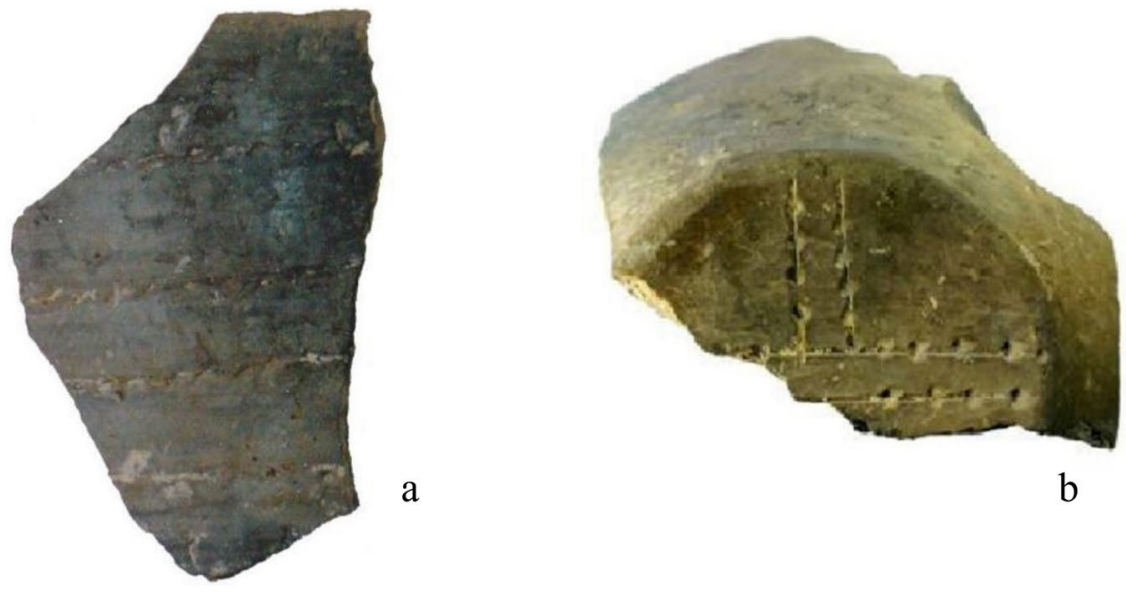

a

b

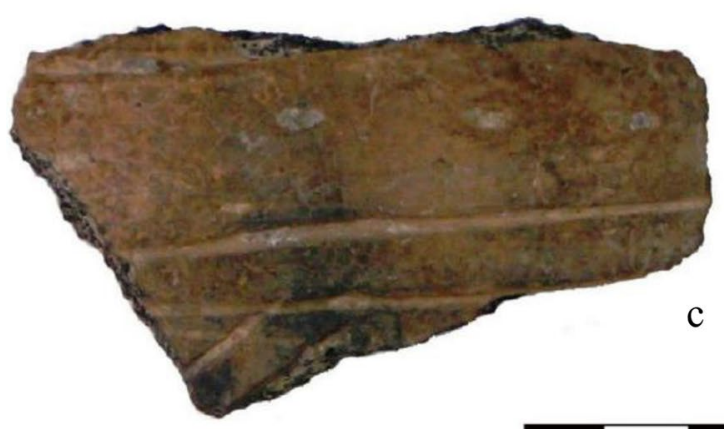

c

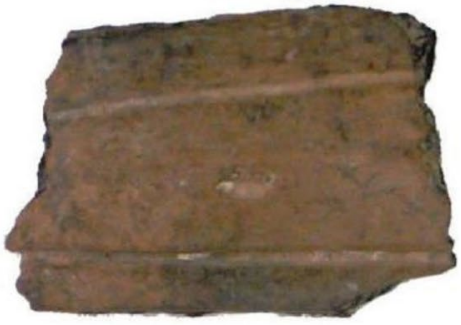

$5 \mathrm{~cm}$ composition to GEO 3; however, micrite is less frequent, and there are no shell fragments (Fig. 8d). In all the samples, opaques and clay pellets were detected. The latter are rounded and equant and discordant, with sharp to clear boundaries and high to neutral optical density. Quartz inclusions are often observed within these clay pellets.

Finally, GEO 5 is a coarse sand sample (Fig. 8e-f). The average size of inclusions is $0.50 \mathrm{~mm}$. The dominant inclusions are quartz, feldspars (plagioclase), and foliated metamorphic rocks composed only of quartz or quartz and mica (muscovite and biotite). Commonly biotite is occurring, while muscovite and chert are rare.

\section{XRPD analysis}

The XRPD analysis run on the clay samples (Fig. 8g) confirms the presence of quartz, feldspars, and calcite. In addition, the weak peak observable in all samples with a $d$ value of approximately $14 \AA\left(6.193^{\circ} 2 \theta\right)$ could indicate the presence of chlorite and/or montmorillonite whose main peaks overlap. Finally, the peak present at approximately $10 \AA$ $\mathrm{d}$-spacing $\left(8.836^{\circ} 2 \theta\right)$ and particularly intense in sample $\mathrm{G} 1$ indicates muscovite but could also suggest the presence of illite, whose main peak overlaps with muscovite.

\section{Archaeological samples}

\section{Petrographic analysis}

The petrographic analysis shows that the samples examined (Table 2) can be clearly divided into three fabrics, according mainly to the nature of the inclusions, clay matrix, and textural characteristics. Most samples can be assigned to fabric 1 , marked by grog tempering. The remaining samples can be classified in fabrics 2 (fine fabric) and 3 (chaff-tempered fabric). The analysis followed the methodology and terminology presented in Quinn (2013). In the next paragraphs, a summary of the main characteristics of these fabrics is provided, and a full description for the largest group (fabric 1) can be found in Supplementary materials 3 and 4.

Samples assigned to fabric 1 (grog tempered fabric, Fig. 9a-e) form a heterogeneous group, marked by the presence of grog tempering. The inclusions range between 20 and $40 \%$, and the grain size distribution is weakly bimodal to bimodal. Generally, the inclusions are poorly to moderately sorted, but in some cases, they are well sorted (e.g. RAD 18, Fig. 9a). Grog is the predominant to dominant type of inclusion in most of the analysed samples attributed to fabric 1 . This tempering agent has been recognised from its textural characteristics as described in the literature (Whitbread 1986: 1989; Cuomo di Caprio and Vaughan 1993). The 
Fig. 8 Thin section photomicrographs of selected geological samples collected around Radovanu: a GEO 1 (XP) fine noncalcareous sandy clay; b GEO 2 (XP) fine non-calcareous sandy clay; c GEO 3 (XP) medium fine non-calcareous sandy clay; d GEO 4 (XP) medium fine non-calcareous sandy clay; $\mathbf{e}, \mathbf{f}$ GEO 5 (XP) coarse sand; $\mathbf{g}$ $\mathrm{X}$-ray diffractograms of selected geological samples from the area around Radovanu. Mineral abbreviations from Whitney and Evans 2010
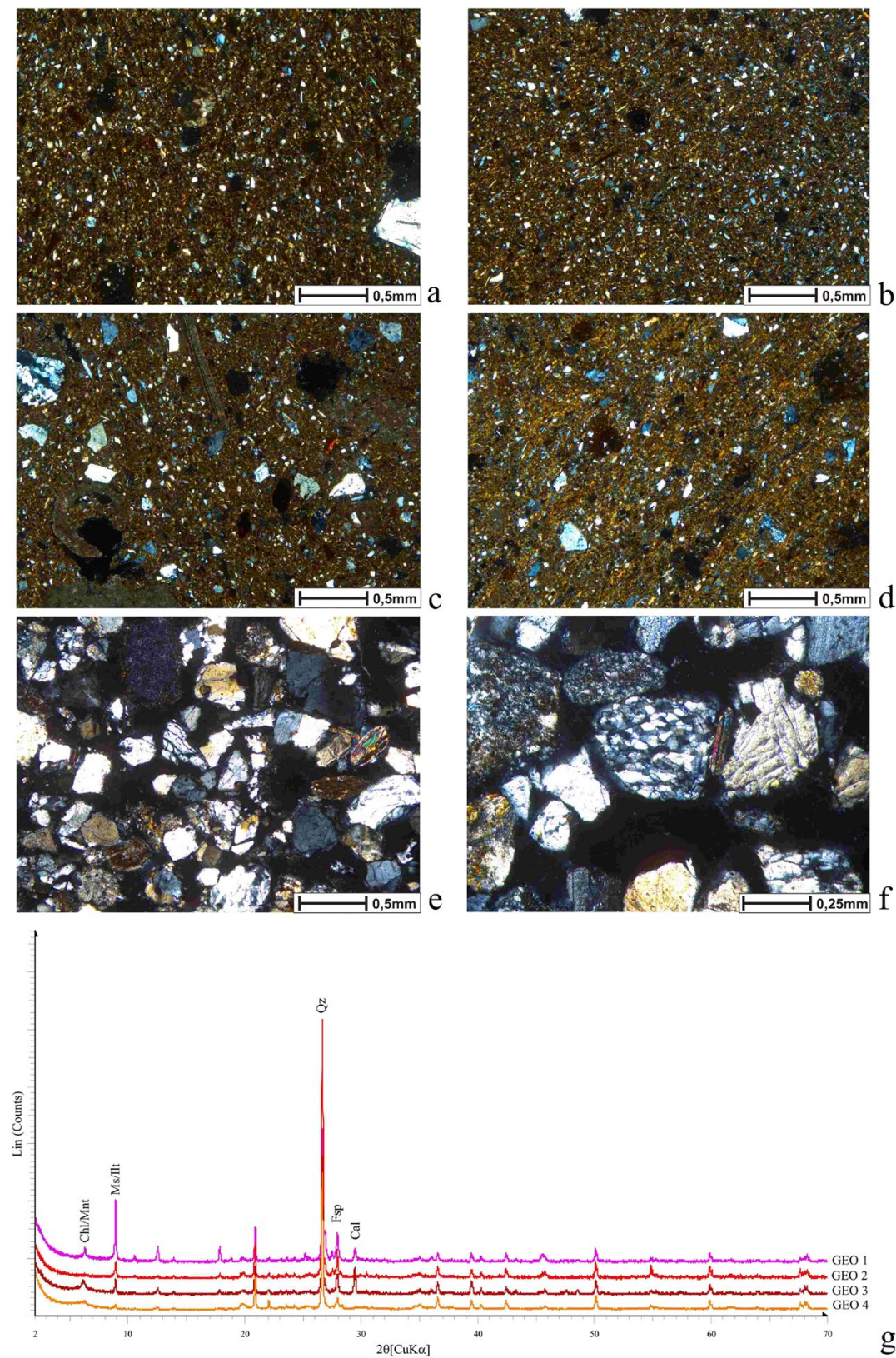

matrix colour of the grog spans from black to orange-brown and light yellow under XP, and it is marked by the same range of inclusions observed in fabric 1 (see below). Based on type of inclusion, coarseness, and matrix colour, seven different types of grog (Table 3, Fig. 10a-h) could be recognised. Detailed description of the petrographic characteristics of each type of grog is provided in Supplementary materials 4. A lineage of grog (i.e. grog-in-grog) was also sometimes present in the pottery fabric (Fig. 10d).

Within fabric 1, aside from grog, quartz also is a dominant inclusion, while micrite is usually frequent. Other minerals include muscovite and feldspars (plagioclase) that are frequent to common and shells (see below sub-group 2), epidote, and metamorphic rocks that are rare. Textural concentration features interpreted as clay pellets are observed in most of the samples. Generally, they are discordant, and they have clear to merging boundaries and usually a low optical density. Sometimes they contain quartz fragments.

The clay matrix of fabric 1 is non-calcareous and ranges from light yellow to dark brown in XP. Inhomogeneity in the colour of the matrix within samples (e.g. RAD 11, RAD 12, RAD 28, RAD 37) is connected to the presence of distinctive firing horizons and clay laminations (e.g. Figure 9c). The optical activity of the matrix is in most of the samples 
Fig. 9 Thin section photomicrographs of selected ceramics from Radovanu analysed in this study: a RAD 18 (XP), fabric 1, sub-group 1; b RAD 29 (XP), fabric 1, sub-group 2; $\mathbf{c}$ RAD 37 (XP), fabric 1, sub-group 3; d RAD 6 (XP), fabric 1, subgroup 4; e RAD 41 (XP), fabric 1, sub-group 5; f RAD 47 (XP), fabric 2; g RAD 49 (XP), fabric 2; h RAD 48 (XP), fabric 3
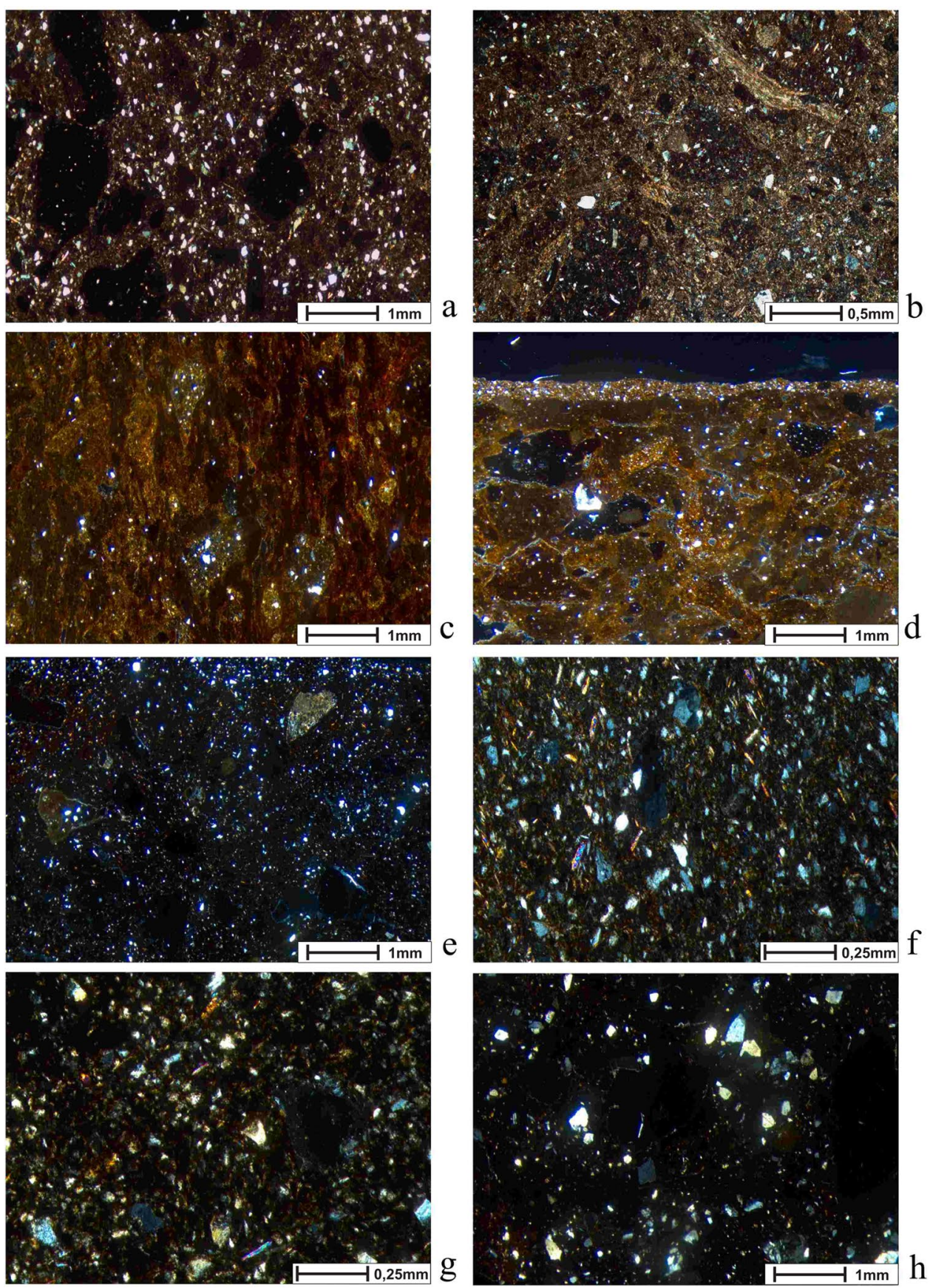

moderate, even though in a group of specimens (see below sub-group 5), they are not optically active.

In this fabric, voids are mainly characterised as channels and vughs, while less frequently planar voids and vesicles are attested. The preferred orientation of the voids and inclusions in some samples (Fig. 9a) could suggest the presence of relic coils. Finally, few samples show the presence of a clay slip layer marked by a fine texture (Fig. 9d). Further classification of fabric 1 in five sub-groups signifies internal differences especially in terms of the abundance and grain size distribution of inclusions and characteristics of the clay matrix. Sub-group 1 (Fig. 9a) is characterised by non-calcareous matrix and by high degree of internal variety in terms of the relative abundance of the inclusions and coarseness. Sub-group 2 (Fig. 9b) is distinctive because of the high concentration of shell fragments. Unfortunately, due to alteration by firing, it is not possible to narrow down to shell species. Sub-group 3 (Fig. 9c) is marked by the presence of grog type $\mathrm{G}$ (Table 3 , Fig. $10 \mathrm{~g}$, h). This type of grog is not present in any other sub-group. Samples attributed to sub-group 4 (Fig. 9d) contain various types of grog and micritic calcite, quartz, and rarely plagioclases. In addition, 
Table 3 Details of the grog types found in fabric 1

\begin{tabular}{llll}
\hline Grog type & Coarseness & Colour of matrix under XP & Visible inclusions \\
\hline A & Fine & Dark brown & Qz, Ms \\
B & Medium-coarse & Dark brown & Qz, Ms, micritic Cal, metamor- \\
& & & phic rock fragments \\
C & Medium-coarse & Light yellow & Qz, Ms, micritic Cal \\
D & Fine & Brown & Qz, grog \\
E & Coarse & Light grey & Qz, clay pellets/Grog, micritic Cal \\
F & Very fine & Black & Very few Qz inclusions \\
G & Fine & Orange-brown/yellowish-brown & Qz, Ms, clay pellets, grog \\
\hline
\end{tabular}

Fig. 10 Grog types: a grog type A (RAD 25), b grog type B (RAD 3), c grog type C (RAD 1), d grog type D (RAD 28), e grog type $\mathrm{E}$ (RAD 7), f grog type $\mathrm{F}$ (RAD 26), g grog type $G$ (RAD 23), h grog type $G$ (RAD 23)
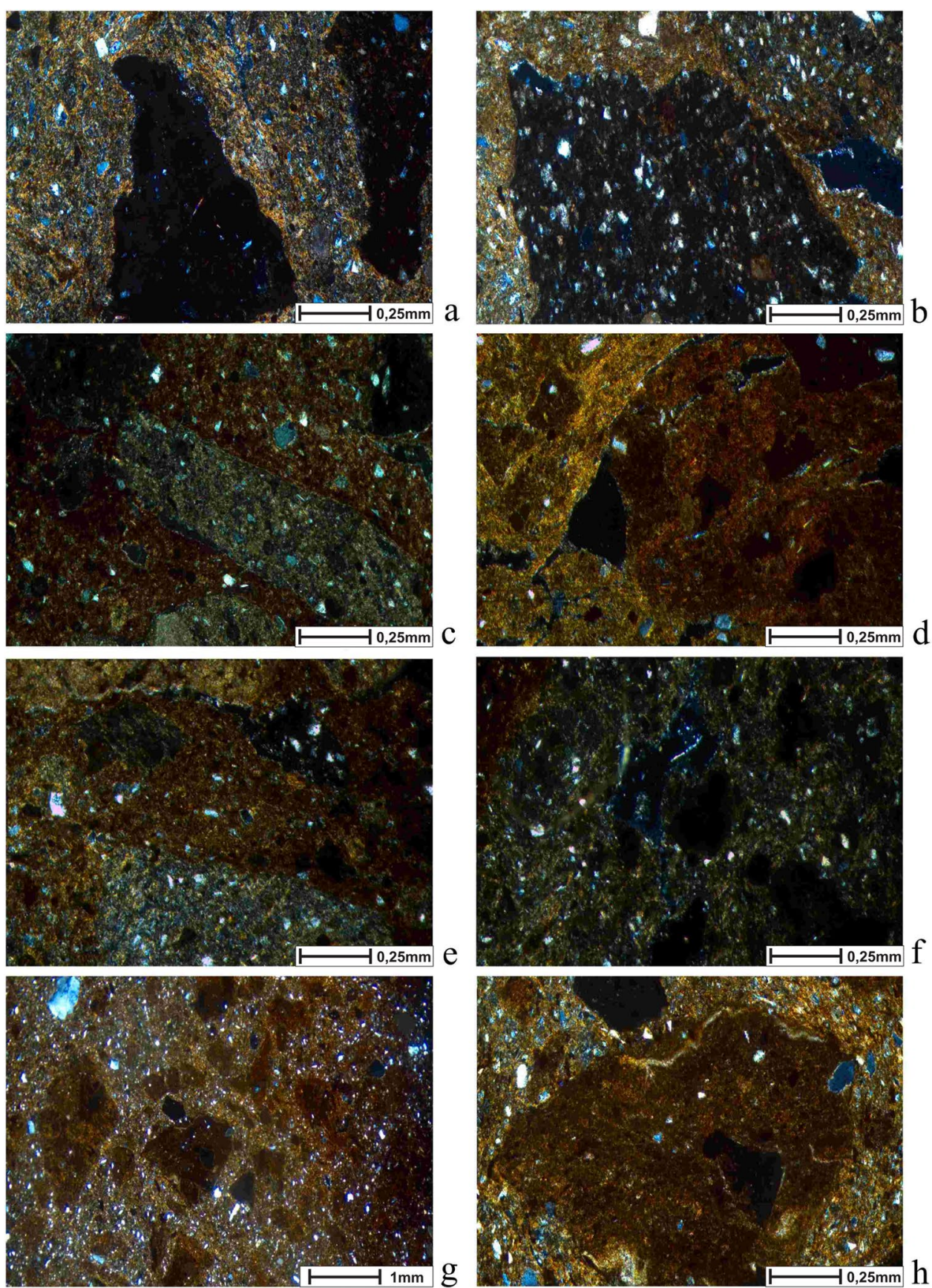
the matrix of this sub-group has a distinctive orange-brown to yellowish-brown colour. Finally, sub-group 5 (Fig. 9e) is marked by an optically inactive matrix, due to exposure to higher temperatures.

Fabric 2 (RAD 47 and RAD 49, fine fabric, Fig. 9f, g) is represented by two samples marked by a fine texture, probably obtained through clay refinement (e.g. levigation). The inclusions range around $30-40 \%$, and their average size is $0.08 \mathrm{~mm}$. This fabric is dominated by quartz, while muscovite and feldspars (plagioclase) are common, and epidote appears very rarely. The matrix is homogeneous, non-calcareous, brown to dark brown, and has a low optical activity. The voids in fabric 2 are characterised as planar and vughs. Both the absence of grog tempering and a fine texture distinguish fabric 2 from fabric 1. Fabric 3 (RAD 48, coarse, chaff-tempered fabric, Fig. 9h) is represented only by one sample which is characterised by a coarse texture. The inclusions in this sample range around $20 \%$, and their average size is $0.6 \mathrm{~mm}$. Quartz is dominant, while micrite and fragments of foliated metamorphic rocks composed of quartz are frequent. Epidote and feldspars (plagioclase and perthite) are also common, while muscovite is rare. The presence of chaff tempering is indicated by the occurrence of elongate voids left from burnt organic material. The matrix is homogeneous, non-calcareous, light brown, with low optical activity. This fabric is differentiated from fabrics 1 and 2 due to the absence of grog and the presence of organic tempering.

\section{XRPD and SEM analyses}

XRPD analyses run on a selection of samples from fabric 1 (Fig. 11) confirmed the presence of quartz, feldspars, and calcite that were observed under the microscope. In sample RAD 24, a weak intensity with a d-spacing at approximately $14 \AA$ (6.193 $2 \theta$ ) is visible, which could indicate the presence of chlorite and/ or montmorillonite. All samples show at peak at approximately $10 \AA \mathrm{d}$-spacing $\left(8.836^{\circ} 2 \theta\right)$ that could indicate muscovite but also illite.

Despite the limits imposed by difficulties in differentiating certain clay minerals, the possible presence of the clay mineral illite in the archaeological samples could indicate that the maximum temperature of firing should have been below $850-900{ }^{\circ} \mathrm{C}$, at which the crystalline structure of this mineral is destroyed. For the sample RAD 24 that shows a weak peak at d-spacing at approximately $14 \AA$, even lower temperatures could be suggested as chlorite or montmorillonite decompose at around $700{ }^{\circ} \mathrm{C}$ and $500{ }^{\circ} \mathrm{C}$, respectively (Amicone et al. 2021).

Relatively low firing temperatures are also suggested by the results of the SEM analysis. The microstructure of the samples analysed via SEM (Fig. 12) in fresh fracture shows no degree of vitrification or only initial vitrification (RAD 40; RAD 44, Fig. 9g, h). This microstructure is compatible with temperatures below $800{ }^{\circ} \mathrm{C}$ and above $750{ }^{\circ} \mathrm{C}$ at least in samples RAD 40 and RAD 44 (Maniatis and Tite 1981).

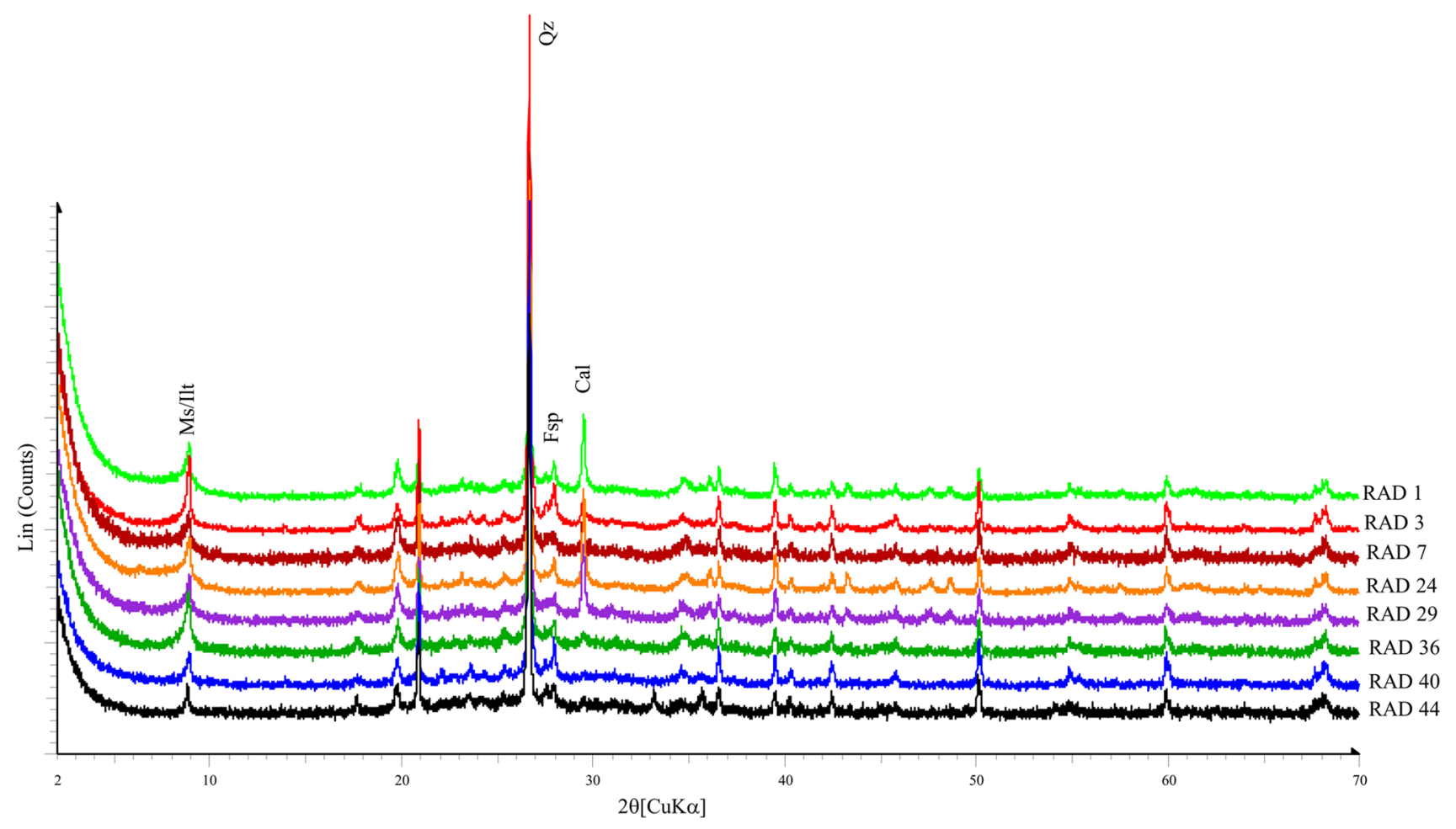

Fig. 11 X-ray diffractograms of selected pottery sherds from Radovanu. Mineral abbreviations from Whitney and Evans 2010 (created by S. Amicone) 
Fig. 12 Vitrification microstructure of selected pottery sherds from Radovanu, as seen in the SEM under secondary electron imaging: a RAD 1; b RAD 3; c RAD 7; d RAD 24; e RAD 29; f RAD 36; g RAD 40; h RAD 44 (created by S. Amicone)
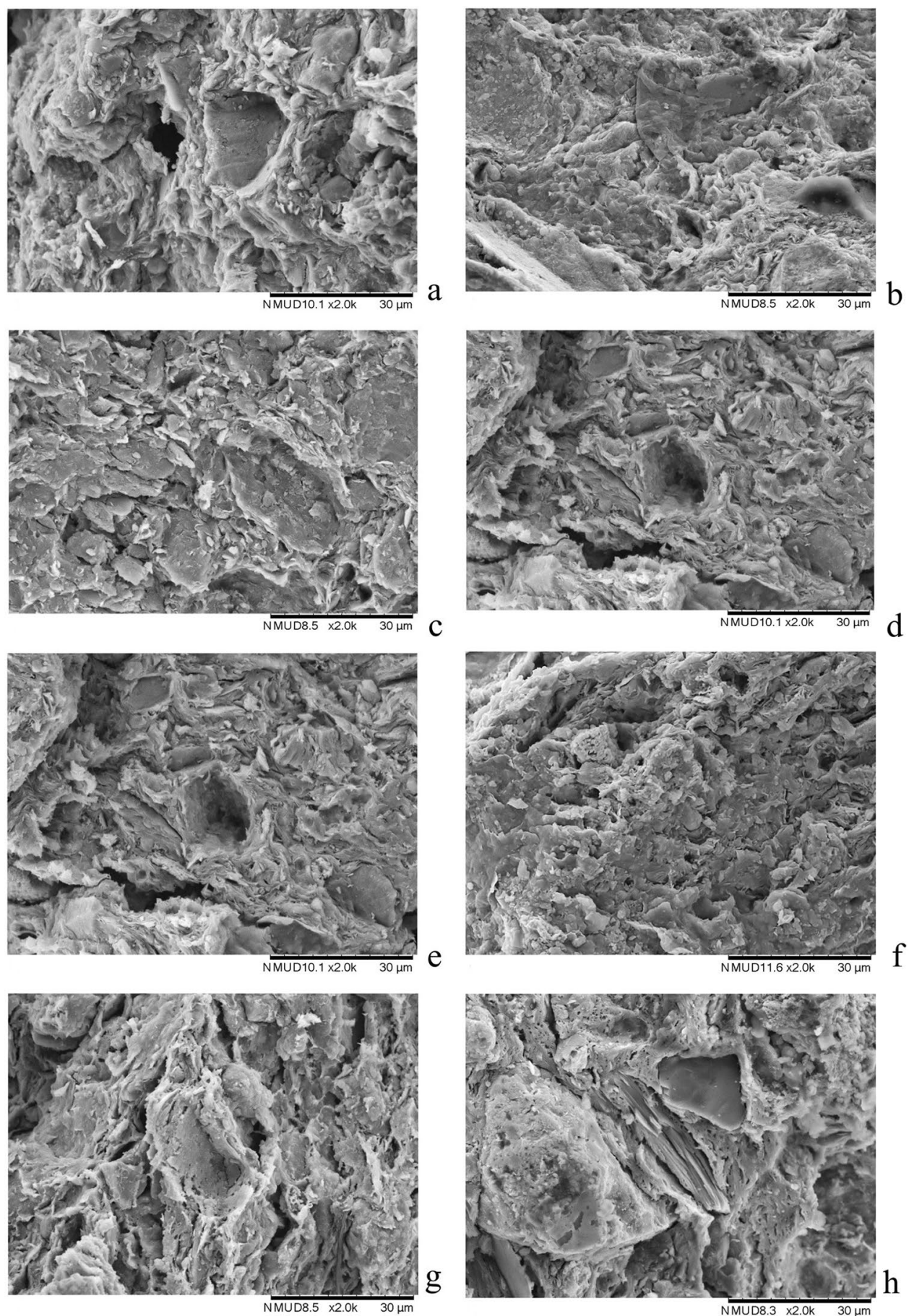

\section{Discussion}

\section{Local pottery production}

Several lines of evidence indicate that fabric 1, marked by grog tempering, represents the local production of Radovanu. This is the most attested fabric at the site, and its mineralogical characteristics align with the composition of the geological samples analysed. In addition, our investigation enabled the reconstruction of several technological aspects of the pottery making tradition at Radovanu.

\section{Clay procurement}

The first step in pottery manufacture is the selection of the raw materials. The results show that potters obtained their clay near the site of Radovanu, taking advantage of the various clay sources available. This is in line with the 
ethnographic studies lead by Arnold on 110 cases examined in different parts of the world, which show that $85 \%$ of the potters took advantage of clay sources within $7 \mathrm{~km}$ from their working areas. Indeed, in most of the cases, potters did not travel more than $1 \mathrm{~km}$ (Arnold 1980, 1985; Rice 2015: 130-131). The same patterns of clay procurement can be observed in other Neolithic/Chalcolithic communities in the Balkans (Amicone et al. 2020b and literature therein). It is also interesting to point out that the variability in the composition and coarseness of the clay matrix of fabric 1 well reflects that of the sandy clay samples collected around Radovanu. These include very fine to medium fine non-calcareous clays marked by the presence of the same range of minerals observed in the archaeological samples. Additionally, GEO 4 is characterised by the presence of shell fragments that seem to be like those were found in sub-group 2 of fabric 1 . This suggests that clay sources with naturally occurring shells were available around Radovanu.

\section{Clay processing}

The processing of the raw material concerns the removal and/ or addition (tempering) of aplastic materials through various procedures (Rice 2015: 133-135; Eramo 2020). In the case of Radovanu, clay could have been refined sometimes through sieving or levigation, as some of the samples are very finetextured (e.g. RAD 9, RAD 16, RAD 21, RAD 32, RAD 38, RAD 39, RAD 42). In addition, clay laminations observed in some of the specimens suggest that potters could have occasionally mixed different types of clays that were available around the site (Ho and Quinn 2021).

The addition of grog as a temper is one of the most striking technological traits of Radovanu pottery production (Comșa 1990; Ștefan 2019). This tradition is attested during the entire lifespan of the site, and its constant use is also indicated by the presence of grog lineages (grog within grog) observed in several samples.

Seven different types of grog were identified in terms of their matrices and inclusions' characteristics (Table 3). This variability well matches the one observed in the pottery assigned to fabric 1 that was the most likely source of grog temper at Radovanu. This means that the local pottery was regularly recycled and added into the clay paste used to manufacturing new pots at this site.

Grog could have been added into the clay paste for functional reasons such as improving mechanical and thermal properties of a vessel, but its choice as a temper may have been driven also by cultural and symbolic factors (Rice 2015: 80). Ethnographic studies reported that grog could be perceived as an ancestral object that was reused within a new item, signifying the strength of tradition and continuity within a community (Barley 1994; Gosselain and Livingston Smith 2005: 41).
The addition of crushed sherds into clay paste was a common practice among potters by the end of the Late Neolithic period (Thissen 2014; Opriş et al. 2017; Spataro 2017; Holmqvist et al. 2018; Mirković-Marić and Amicone 2019; Szakmány et. al. 2019; Amicone et al. 2020b). Within Vinča culture, for example, grog has been used to temper vessels with thick walls such as storage and cooking pots (Amicone et al. 2020b).

At Radovanu, grog is not found in connection to a specific type of vessel but rather occurs throughout. Moreover, our geological survey made clear that other types of suitable tempers such as sand (GEO 5) were available but not used. This could imply that the choice of grog was dictated by a strong tradition rather than functional factors alone.

\section{Forming, finishing, and decoration}

The combination of macroscopic and archaeometric analysis carried out in this investigation enabled insights on forming, finishing, and decoration techniques utilised by potters. Macro-traces observed on the pottery sherds such as preferential fractures (Roux 2017: 200-206) and relic coils detected through petrographic analysis (Quinn 2013: 177) confirmed that the primary technique for forming vessels was coiling throughout the different phases of the settlement. This is one of the most widely attested pottery-forming technique in the Balkans in the Chalcolithic period (Amicone et al. forthcoming). Finishes such as smoothing and burnishing are applied to most of the samples, and petrographic analysis confirmed the applications of clay slips made from a very fine clay. Finally, the variety of decoration techniques recognised provide evidence of the mastery of potters at Radovanu while also showing the wider connection of technological know-how in the ancient Balkans (Bonga 2013).

\section{Pyrotechnology}

The study of surface and cross-section colour of the samples shows that firing in both oxidising and reducing (twostep procedure) could have been applied. Additionally, archaeometric analyses indicate that the firing temperatures employed could not have exceeded $850{ }^{\circ} \mathrm{C}$ on a regular basis (Maniatis and Tite 1981; Karkanas 2007; Matias et al. 2014). Control of reducing conditions were crucial for graphitedecorated pots, as the crystalline structure of graphite starts to deteriorate above $700{ }^{\circ} \mathrm{C}$ under oxidising conditions (Kreiter et al. 2014; Amicone 2017: 236; Amicone et al. 2020a). These temperatures and conditions could be easily reached in both kilns and pit firing installations. As mentioned above, a bell-shaped feature found at Radovanu is currently interpreted as a firing pit due to the presence of combusted walls (Comșa 1990: 66; Ștefan 2019: 148-149). This feature could 
suggest that pit firing was the type of installation used at this site. Without denying that kilns certainly existed at that time, pit firing could have been an efficient alternative installation. This was also suggested for Vinča ceramics, as no secure evidence of kilns has been found at Vinča sites (Vuković 2018; Amicone et al. 2021).

\section{Organisation of production}

The stability of the technological tradition of ceramic manufacture at Radovanu can be supported by the continuity of grog tempering practices throughout the life of this site. This 'conservatism' can also be observed through other technological traits, such as forming, finishing, and decorative techniques. In the absence of clear evidence of workshops, it is difficult to understand which level of specialisation the potters at this Radovanu reached (Costin 1991; Rice 1991). The technological similarities observed in the studied assemblage could be the effect of a strong technological tradition rather than standardisation.

What we can propose, however, is that these potters were skilled, as shown by the variety of decoration techniques they were able to master. Such mastery suggests having good knowledge of the raw materials and their firing behaviours (Forte 2019). Therefore, it is possible to assume that a certain level of specialisation marked Radovanu pottery production and that some individuals could have invested enough time in the apprenticeship for ceramic manufacturing to become masters in various categories of decorative and related firing techniques.

\section{Interregional connections}

Samples marked by fabrics 2 and 3 deserve a separate discussion. The stylistic characteristics of these sherds connect them to the Hamangia (RAD 49), Vinča (RAD 47), and Precucuteni (RAD 48) material cultures (Fig. 1).

In general, it is not uncommon to find pottery in Boian sites marked by elements typical of other contemporaneous cultural phenomena. For example, Hamangia (5250-4500 BCE) sherds were found at Isaccea-Suhat and Giulesti (Berciu 1966; Haşotti 1997), while Precucuteni (4800-4000 BCE) pottery is attested at Tangaru and Vidra (Marinescu-Bîlcu 1974; Garvăn 2013). It is also known that in Vinča culture (5700-4200 BCE) (Whittle et al. 2016 and literature therein), pottery and figurines were exchanged, sometimes reaching distant areas (Ștefan 2014b; Amicone 2017; Amicone et al. forthcoming). At the same time, Boian pottery has been found in other material cultural areas such as Hamangia (e.g. the site of Cheia) (Ștefan 2014b). Even if the compositional characteristics of the 'foreign' samples found at Radovanu (fabrics 2 and 3 ) are slightly different from those of fabric 1 , they do not necessarily rule out a local production. Future work that applies geochemical analysis to these samples could further clarify this issue. Nevertheless, these specimens do not contain any grog, which has been exemplified to be a typical trait of Radovanu production. This could lead to the hypothesis that either these pots were brought to Radovanu or at least that they were made according to a tradition that is not the typical one of this locality. This second hypothesis seems to be less likely, considering the conservative pottery tradition that marks this community and the limited number of 'foreign' sherds found at Radovanu (nine in total).

Interregional connections are not only displayed by the presence of these nine sherds at Radovanu. The use of coiling, grog, and the various pottery decorative techniques attested at this site shows how this community of potters was well integrated in the wider prehistoric Balkans technological traditions (e.g. Micu 1999; Todorova 2003; Thissen 2014; Amicone 2017; Opriş et al. 2017; Spataro 2017).

The best example of this integration is the use of graphitepainted decoration, a widespread phenomenon throughout the Balkans in the fifth millennium BCE that links sites such as Serbia, Bulgaria, Greece, North Macedonia, and Romania. The application of this technique implies a nuanced understanding of the balance of redox firing conditions and two-step firing procedure. It also requires the participation in specialist trade networks for the procurement of graphite (Amicone et al. 2020a). Graphite sources are found in Bulgaria, especially in the Rhodope area (Leshtakov 2005), but also in the mountainous areas in Northern and Central Romania (Radu 2006). The presence of this decorative technique at Radovanu shows that this site was not only part of this long-distance trade network, but also suggests that it shared an aesthetic taste with other communities from the prehistoric Balkans for materials with striking colours and light-reflective qualities (Chapman 2007).

\section{Conclusions}

Our study, which combines archaeological and archaeometric analyses on pottery and clay samples from Radovanu, allows us to elucidate on different aspects connected to pottery manufacturing at this site.

Our results show that pottery production in Radovanu has remained stable for the entire lifespan of the site. While compositional and textural variability observed via ceramic petrography are probably the result of the variable clay sources available around the site, the main clay recipe (i.e. grog tempering), forming, and decorative techniques are consistent throughout the timespan in which the site was inhabited. This suggests that the transmission of knowledge for pottery manufacture at the site was probably vertical and 
direct from parents to offspring (Cavalli-Sforza and Feldman 1981) and marked by firmly installed and long-lasting apprentice networks as it was observed in contemporary sites (Amicone 2020b).

Even though a conservative local tradition is the hallmark of the local production at Radovanu, the results show several technological elements that connect this site to the wider Balkan region such us the use of grog and various decorative techniques like graphite painting.

Additionally, the presence of 'foreign' pottery further illustrates the complex interrelationships between the Boian phenomenon and the neighbouring material cultures. This certainly only gives us a glimpse of the far more complex economic system that entailed the exchange of raw materials, objects, technical knowledge, and ideas that mark the Late Neolithic and Chalcolithic period in Balkans (e.g. Leshtakov 2005; Mărgărit et al. 2014; Radivojević and Grujić 2018). Certainly, Radovanu benefitted from its strategic geographic position, being near the Danube River, which was the main route of communication in this region at that time.

Overall, our results indicate a community of potters permeable to a shared technological know-how that resonated on a wide temporal and geographical scale. Potters from Radovanu, by combining these shared technological traits and adapting them to their landscape, developed a conservative technological tradition that suggests the presence of a stable and strong pottery apprenticeship network.

Supplementary Information The online version contains supplementary material available at https://doi.org/10.1007/s12520-021-01417-x .

\section{Additional data that support the findings of this study (additional sample pictures and thin section micrographs) are openly available at https://doi.org/10.7910/DVN/NOTBMZ.}

Acknowledgements This project was carried out in the frame of an Erasmus+ placement and M.Sc. programme at the University of Tübingen and as part of the Memorandum of Understanding between the Competence Center Archaeometry - Baden-Wuerttemberg (University of Tübingen) and the Institute of Archaeology of the Romanian Academy Romania: A technological approach to the study of Pottery from Radovanu.

We would like to thank for their help and feedback Aspen Cooper, Lars Heinze, Mihai Florea, Stella Vougioukelli, and Vangelis Samaras. S. A. and C. B. would also like to acknowledge the Excellence Initiative (Eberhard Karls Universität Tübingen), the Ministry for Science, Research, and Art of Baden-Württemberg and the Klaus Tschira Stiftung, for their support during the preparation of this article. Constructive comments by reviewers and the editor helped us strengthen the paper and are much appreciated. All remaining shortcomings are ours.

Author contribution Eirini Koutouvaki: conceptualisation, methodology, formal analysis (ceramic petrography), investigation, writing original draft, review and editing the final draft, and visualisation.

Silvia Amicone: conceptualisation, methodology, investigation, resources, review and editing original and final draft, visualisation, supervision of the project and formal analysis (petrography, SEM and XRD), and project administration.

Andrean Kristew: methodology, formal analysis (SEM and XRPD), review and editing final draft, and visualisation.

Christian Eduard Ştefan: conceptualisation, investigation, review and editing final draft, visualisation, and project administration.

Christoph Berthold: methodology, investigation, resources, review and editing final draft, supervision of formal analysis (XRPD), and funding acquisition.

Funding Open Access funding enabled and organized by Projekt DEAL.

\section{Declarations}

Disclosures This manuscript contains original research, and we confirm that it has not been published elsewhere and is not under consideration by another journal. All authors have read and approved the manuscript and agree with its submission to the Archaeological and Anthropological Sciences Journal.

Conflict of interest The authors declare no competing interests.

Open Access This article is licensed under a Creative Commons Attribution 4.0 International License, which permits use, sharing, adaptation, distribution and reproduction in any medium or format, as long as you give appropriate credit to the original author(s) and the source, provide a link to the Creative Commons licence, and indicate if changes were made. The images or other third party material in this article are included in the article's Creative Commons licence, unless indicated otherwise in a credit line to the material. If material is not included in the article's Creative Commons licence and your intended use is not permitted by statutory regulation or exceeds the permitted use, you will need to obtain permission directly from the copyright holder. To view a copy of this licence, visit http://creativecommons.org/licenses/by/4.0/.

\section{References}

Amicone S, Radivojević M, Quinn PS, Rehren TH (forthcoming) Pottery technology at the dawn of metallurgy in the Vinča culture. In: Radivojević M, Roberts BW, Marić M, Kuzmanović-Cvetković $\mathrm{J}$, Rehren T (eds) The rise of metallurgy in Eurasia. Evolution, organisation and consumption of early metal in the Balkans. Archaeopress, Oxford, pp. 538-551. https://doi.org/10.32028/ 9781803270425

Amicone S, Forte V, Solard B, Berthold C, Memmesheimer A, Mirković-Marić N (2021) Playing with fire: exploring ceramic pyrotechnology in Late Neolithic Balkans through an archaeometric and an experimental approach. J Archaeol Sci Rep 37. https:// doi.org/10.1016/j.jasrep.2021.102878

Amicone S, Radivojević M, Quinn PS, Berthold C, Rehren TH (2020a) Pyrotechnological connections? Re-investigating the link between pottery firing technology and the origins of metallurgy in the Vinča Culture, Serbia. J Archaeol Sci 118:105-123. https://doi. org/10.1016/j.jas.2020.105123

Amicone S, Mathur AR, Rengasamy DP, Mirković-Marić N, Pantović I, Kuzmanović-Cvetković J (2020b) Beneath the surface: exploring variability in pottery paste recipes within Vinča culture, Serbia. Quat Int 560-561: 86-101. https://doi.org/10. 1016/j.quaint.2020.04.017 
Amicone S (2019) Introduction. Tracing pottery-making recipes in the prehistoric Balkans, 6th-4th Millennia BC. In: Amicone S, Quinn PS, Miroslav M, Mirković-Marić N, Radivojević M (eds) Tracing pottery-making recipes in the prehistoric Balkans, 6th-4th Millennia BC. Archaeopress, Oxford, pp 1-7

Amicone S (2017) Pottery technology at the dawn of Metal Age: a view from Vinča culture. Dissertation, University College of London. https://scholar.google.com/citations?view_op=view_citat ion $\&$ hl $=$ it $\& u s e r=$ Taog_IwAAAAJ $\&$ cstart $=20 \&$ pagesize $=80 \&$ sortby $=$ pubdate $\&$ alert_preview_top_rm $=\&$ citation_for_view $=$ Taog_IwAAAAJ:ufrVoPGSRksC

Arnold DE (1985) Ceramic theory and cultural process. Cambridge University Press, Cambridge

Arnold DE (1980) Localized exchange: an ethnoarchaeological perspective. In: Fry RE (ed) Models and methods in regional exchange. Society for American Archaeology Papers 1, Oxford, pp 147-150

Bailey DW (2000) Balkan Prehistory. Exclusion, incorporation and identity. Routledge, London and New York

Barley N (1994) Smashing pots: feats of clay from Africa. British Museum Press, London

Bem C (2000-2001) Noi propuneri pentru o schiţă cronologică a eneoliticului românesc. Pontica 33-34:25-121

Berciu D (1966) Cultura Hamangia. Editura Academiei Republicii Socialiste România, București, Noi contribuții I

Bonga L (2013) Late Neolithic pottery from Mainland Greece, ca. 5,300-4,300 BC. Unpublished Dissertation, Temple University Graduate Board

Borić D (2015) The end of the Vinča world: modelling the Neolithic to Copper Age transition and the notion of archaeological culture. In: Hansen S, Raczky P, Anders A, Reingruber A (eds) Neolithic and Copper Age between the Carpathians and the Aegean Sea. Chronologies and Technologies from the $6^{\text {th }}$ to the $4^{\text {th }}$ Millennium BCE. International Workshop Budapest 2012. Habelt Verlag, Bonn, pp 157-218.

Cavalli-Sforza LL, Feldman M (1981) Cultural transmission and evolution: a quantitative approach. Princeton University Press, Princeton

Chapman J (2007) The elaboration of an aesthetic of brilliance and colour in the Climax Copper Age. In: Lang F, Reinholdt C, Weilhartner J (eds) Stephanos Aristeios. Ploibos Verlag, Wien, Archäologische Forschungen zwischen Nil und Istros, pp 65-74

Chapman J (1981) The Vinča culture of South-East Europe: studies in chronology, economy and society, BAR International Series 117, Pennsylvania

Childe VG (1957) The dawn of European civilization. Routledge, London

Ciugudean-Toma V, Stefanescu I (2006) Engineering geology of the Bucharest city area, Romania. In: International Association for Engineering Geology Proceedings, Engineering Geology for Tomorrow's Cities, paper no. 235:1-8

Comşa E (1990) Complexul neolitic de la Radovanu. Cultură Şi Civilizaţie La Dunărea De Jos 8:1-124

Comşa E (1974) Istoria comunităţilor culturii Boian. Editura Academiei Republicii Populare România, Bucureşti

Costin CL (1991) Craft specialization: issues in defining, documenting and explaining the organization of production. Archaeol Method Theory 3:1-56

Cuomo di Caprio N, Vaughan S (1993) An experimental study in distinguishing grog (chamotte) from argillaceous inclusions in ceramic thin sections. Archaeomaterials 7:21-40

Dobres MA, Hoffman CR (1994) Social agency and the dynamics of prehistoric technology. J Archaeol Method Theory $1(3): 211-258$

Eramo G (2020) Ceramic technology: how to recognize clay processing, Archaeological and Anthropological Sciences 12 (260)
Faber E, Day P, Kilikoglou V (2009) Fine-grained Middle Bronze Age polychrome ware from Crete: combining petrographic and microstructural analysis. In: Quinn PS (ed) interpreting silent artefacts: petrographic analysis of archaeological ceramics. Archaeopress, Oxford, pp 139-156

Forte V (2019) Skilled people or specialists? Knowledge and expertise in Copper Age vessels from central Italy. J Anthropol Archaeol 55:1-20

Garvăn D (2013) Contribuții la cunoașterea culturii Precucuteni, Ed. Constantin Mătasă, Piatra Neamț

Gliozzo E (2020) Ceramic technology. How to reconstruct the firing process. Archaeological and Anthropological Sciences 12 (260)

Gosselain OP, Livingston Smith A (2005) The source: clay selection and processing practices in sub-Saharan Africa. In: Livingston Smith A, Bosquet D, Martineau R (eds) Pottery manufacturing process: reconstitution and interpretation. British Archaeological Reports, Oxford, pp 33-47

Hașotti P (1997) Epoca neolitică în Dobrogea, Bibliotheca Tomitana, I, Constanța

Holmqvist E, Larsson AM, Kriiska A, Palonen V, Personen P, Mizohata K, Kouki P, Räisänen J (2018) Tracing grog and pots to reveal Neolithic Corded Ware Culture contacts in the Baltic Sea region (SEM-EDS, PIXE). J Archaeol Sci 91:77-91

Ho JWI, Quinn PS (2021) Intentional clay-mixing in the production of traditional and ancient ceramics and its identification in thin section. J Archaeol Sci Rep 37:1-12

Karkanas P (2007) Identification of lime plaster in prehistory using petrographic methods: a review and reconsideration of the data on the basis of experimental and case studies. Geoarchaeol Int J 22(7):775-796

Kreiter A (2010) Ceramic technology and social process in late Neolithic Hungary. In: Quinn PS (ed) Interpreting silent artefacts: petrographic approaches to archaeological ceramics. Archaeopress, Oxford, pp 101-119

Kreiter A, Marton T, Gomart L, Oross K, Pánczél P (2017a) Looking into houses: analysis of LBK ceramic technological change on a household level. In: Burnez-Lanotte L (ed) Matières à Penser. Raw materials acquisition and processing in Early Neolithic pottery productions. Proceedings of the Workshop of Namur (Belgium), 29-30 May 2015. Société préhistorique française, Paris, pp 111-132.

Kreiter A, Kalicz N, Kovács K, Siklósi Z, Viktorik O (2017b) Entangled traditions: Tisza and Lengyel ceramic technology in a Late Neolithic settlement in northern Hungary. J Archaeol Sci 16:285-295

Kreiter A, Czifra S, Bendő Z, Egri Imre Z, Pánczél P, Váczi G (2014) Shine like metal: an experimental approach to understand prehistoric graphite coated pottery technology. J Archaeol Sci 52:129-142

Lemonnier P (1993) Introduction. In: Lemonnier P (ed) Technological choices. Transformation in material cultures since the Neolithic. Routledge, London and New York, pp 1-35.

Lemonnier P (1992) Elements for an anthropology of technology. University of Michigan press, Michigan

Leshtakov P (2005) The sources and distribution of graphite as a means. In: Dimitroaia G, Chapman J, Weller O, Preoteasa C, Munteanu R, Nicola D, Monah D (eds) Cucuteni. 120 years of research. Time to sum up. Piatra-Neamţ, Romania, pp 293-397

Maggetti M (1982) Phase analysis and its significance for technology and origin. In: Olin JS, Franklin AD (eds) Archaeological Ceramics. Smithsonian Institution press, Washington DC, pp 121-133

Maniatis Y, Tite MS (1981) Technological examination of Neolithic Bronze Age pottery from Central and Southeast Europe and from the Near East. J Archaeol Sci 8:59-76 
Maniatis Y, Tite MS (1975) A scanning electron microscope examination of the bloating of fired clays. Trans J Br Ceram Soc 74(8):229-232

Mărgărit M, Ştefan CE, Dumitraşcu V (2014) Management of osseous materials for processing artifacts in the Eneolithic Boian settlement of Radovanu - La Muscalu (Romania). Archaeologia Bulgarica XVIII 3:1-34

Marinescu-Bîlcu S (1974) Cultura Precucuteni pe teritoriul României. Editura Academiei Republicii Socialiste România, Bucuresti

Maritan L (2004) Archaeometric study of Etruscan-Padan type pottery from Veneto region: petrographic, mineralogical and geochemical-physical characterisation. Eur J Mineral 16:297-307

Maritan L, Mazzoli C, Freestone I (2007) Modelling changes in mollusc shell internal microstructure during firing: implications for temperature estimation in shell-bearing pottery. Archaeometry 49:529-541

Martinon S (2017) Graphite-treated pottery in the Northeastern Mediterranean from the Chalcolithic to the Bronze Age. Near Eastern Archaeology 80:3-13

Martineau R (2010) Brunissage, polissage et degrés de séchage. Un référentiel expérimental. Les Nouvelles De L'archéologie 119:13-19

Matias G, Faria P, Torres I (2014) Lime mortars with heat treated clays and ceramic waste: a review. Constr Build Mater 73:125-136

Mentesana R, Kilikoglou V, Todaro S, Day PM (2017) Reconstructing change in firing technology during the final Neolithic-Early Bronze Age transition in Phaistos, Crete. Just the tip of the iceberg? Archaeol Anthropol Sci 9:871-894

Micu C (1999) Ceramica fazei Boian-Spanţov din aşezarea de la Isaccea-Suhat (Boian-Spanţov phase ceramics in Isaccea-Suhat Settlement). Pontica 32:235-242

Mirea P (2009) On Vădastra habitation in Southern Romania: context and results from the Teleorman valley. In: Cotiugă V, Tencariu FA, Bodi G, (eds) Itenaria in praehistorica. Studia In honorem magistri Nicolae Ursulescu. Editura Universitătii "Alexandru Ioan Cuza", Iaşi, pp 281-293

Mirković-Marić N, Amicone S (2019) Technological variances between Tisza and Vinča pottery in the Serbian Banat. In: Amicone S, Quinn PS, Miroslav M, Mirković-Marić N, Radivojević M (eds) Tracing pottery-making recipes in the Prehistoric Balkans, 6th-4th Millennia BC. Archaeopress, Oxford, pp 96-112

Nodari L, Marcuz E, Maritan L, Mazzoli C, Russo U (2007) Hematite nucleation and growth in the firing of carbonate-rich clay for pottery production. J Eur Ceram Soc 27:4665-4673

Opris V, Ştefan CE (2016) The Boian-Spanţov pottery from two pits at Nanov-"Vistireasa 3"'(Teleorman County, Romania). Buletinul Muzeului Judeţean Teleorman, Seria Archeologie 8:33-58

Opriş V, Lazar C, Ignat T (2017) Technological analysis of Boian-Vidra pottery from Sultana. Studii De Preistorie 14:93-109

Opriş V, Mirea DA, Andrei RF, Straticiuc M., Simion CA, Stănculescu I, Miu L, Dincă L (2019) Archaeometric studies of Boian pottery from Nanov- 'Vistireasa 3' (Teleorman County, Romania, c.4800-4500 cal BC) In: Palincaş N, Ponta CC (eds) Bridging science and heritage. Proceedings of the 5th Balkan Symposium of Archaeometry 25th-29th Sept. 2016, Sinaia, Romania. Archaeopress, Oxford, pp 92-102.

Perišić N, Marić-Stojanović M, Andrić V, Mioč UB, Damjanović L (2016) Physicochemical characterisation of pottery from Vinča culture, Serbia regarding the firing temperature and decoration technique. J Serb Chem Soc 81(12):1415-1426

Petrescu I, Mitroi E (1965) Map 44 Bucuresti L-35-XXXIII K-35-III, 1:200000. Geological Institute, Bucarest

Quinn PS (2013) Ceramic petrography: the interpretation of archaeological pottery \& related artefacts in thin section. Archaeopress, Oxford
Radu J (2006) Introducere in geologia zacamintelor. Editura Universitatii din Bucuresti, Bucuresti

Radivojević M, Grujić J (2018) Community structure of copper supply networks in the prehistoric Balkans: an independent evaluation of the archaeological record from the 7th to the 4th millennium BC. J Complex Net 6:106-124

Rice PM (2015) Pottery analysis: a source book, 2nd edn. University of Chicago Press, Chicago

Rice PM (1991) Specialization, standardization, and diversity: a retrospective. In: Bishop RL, Lange FW (eds) The ceramic legacy of Anna O. University Press of Colorado, Niwot, Colorado, Shepard, pp 257-279

Rice PM (1987) Pottery analysis. University of Chicago press, Chicago, A sourcebook

Roux V (2017) De céramiques et des hommes. Presses universitaires de Paris Nanterre, Paris, Décoder les asseblages archéologiques

Rye OS (1981) Pottery technology. Principles and reconstruction, Taraxacum, Washington DC

Spataro M (2018) Origins of specialization: the ceramic chaîne opératoire and technological take-off at Vinča-Belo Brdo Serbia. Oxford J Archaeol 37(3):247-265

Spataro M (2017) Innovation and regionalism in the middle/late Neolithic of south and south-eastern Europe (ca. 5,500-4,500 cal. $\mathrm{BC}$ ): a ceramic perspective. In: Burnez L (ed) Matières à penser. Raw materials acquisition and processing in Early Neolithic pottery productions, Proceedings of the Workshop of Namur (Belgium), 29-30 May 2015.Société préhistorique française, Paris, pp 61-80.

Spataro M, Cubas M, Craig OE, Chapman JC, Boroneanţ A, Bonsall C (2019) Production and function of Neolithic black-painted pottery from Schela Cladovei (Iron Gates, Romania). Archaeol Anthropol Sci 11:6287-6304

Ştefan CE (2019) Some aspects concerning pottery making at Radovanu-La Muscalu, Romania (first half of the 5th Millennium BC). In: Amicone S, Quinn PS, Miroslav M, Mirković-Marić N, Radivojević $\mathrm{M}$ (eds) Tracing pottery-making recipes in the Prehistoric Balkans, 6th-4th Millennia BC. Archaeopress, Oxford, pp 142-152

Ştefan CE (2014a) Câteva date despre locuirea de tip Boian-Vidra de la Radovanu- La Muscalu, jud. Călărași-Some Data About BoianVidra type Habitation from Radovanu-La Muscalu, Călărași County. Analele Banatului XXII: 155-164

Ştefan CE (2014b) Relații de schimb în Eneoliticul timpuriu la Dunărea de Jos (ca. 5000-4500 a. Chr.)/Exchange relationship during Early Chalcolithic at Lower Danube (ca. 5000-4500 BC). In: Măndescu D (ed) Lucrările colocviului naţional desfăşurat la Cumpăna, 2-4 octombrie 2013. Editura Ordessos, Piteşti, pp 9-18

Stojanovski D, Nacev T, Arzarello M (2014), Pottery typology and the monochrome Neolithic phase in the Republic of Macedonia. In: Schier W, Draşovean F (eds) The Neolithic and Eneolithic in Southeast Europe. New approaches to dating and cultural Dynamics in the 6th to 4th Millennium BC, Verlag Marie Leidorf GmbH, Rahden-Westf., pp 9-28

Szakmány G, Vanicsek K, Bendő Z, Kreiter A (2019) Petrological Analysis of Late Neolithic Ceramics from the Tell Settlement of Gorzsa (South-East Hungary). In: Amicone S, Quinn PS, Miroslav M, Mirković-Marić N, Radivojević M (eds) Tracing PotteryMaking Recipes in the Prehistoric Balkans, 6th-4th Millennia BC. Archaeopress, Oxford, pp 156-171

Thissen L (2013) Middle Neolithic ceramics from TELEOR 003, Southern Romania. Buletinul Muzeului Județean Teleorman 5:25-123

Thissen L (2014) Boian period ceramics from Teleor 008, a site in South of Romania. Studii De Preistorie 11:97-113

Tite MS, Maniatis Y (1975a) Scanning electron microscopy of fired calcareous clays. Trans J Br Ceram Soc 74(1):19-22 
Tite MS, Maniatis Y (1975b) Examination of ancient pottery using the scanning electron microscope. Nature 257:122-123

Todorova H (1995) The Neolithic, Eneolithic and Transitional Period in Bulgarian Prehistory. In: Bailey DW, Panayotov I (eds) Prehistoric Bulgaria. Monographs in World Archaeology 22. Prehistory press, Madison, pp 79-98

Todorova H (2003) Praehistory of Bulgaria. In: Grammenos D (ed) Recent research in the prehistory of the Balkans, Publications of the Archaeological Institute of Northern Greece 3, Thessaloniki, pp 257-328

Van der Leeuw SE (1989) Risk, perception and innovation. In: Van der Leeuw SE, Torrence R (eds) What's new? A closer look at the process of innovation. Unwin Hyman, London, pp 300-327

Van der Leeuw SE (1993) Giving the potter a choice, Conceptual aspects of pottery techniques. In: Lemonnier P (ed) Technological Choices. Transformation in Material Cultures since the Neolithic. Routledge, London and New York, pp 238-288

Voinea V, Neagu G (2008) Archaeological research at Hamangia III settlement from Cheia (2004 - 2008). Pontica XLI: 9-34

Vuković J (2013) Description vs interpretation: the attitudes of traditional and current archaeology towards the problem of impressobarbotine in the Early Neolithic. Issues Ethnol Anthropol $8(3): 657-79$

Vuković J (2018) Late Neolithic Vinča pottery firing procedure. Opuscula Archaeologica 39(40):25-35
Whitbread IK (1989) A proposal for the systematic description of thin sections towards the study of ancient ceramic technology. In: Maniatis Y (ed) Archaeometry: Proceedings of the 25th International Symposium. Elsevier, Amsterdam, pp 127-138

Whitbread IK (1986) The characterisation of argillaceous inclusions in ceramic thin sections. Archaeometry 28(1):79-88

Whitney DL, Evans BW (2010) Abbreviations for names of rockforming minerals. Am Miner 95:185-187

Whittle A, Bayliss A, Barclay A, Gaydarska B, Bánffy E, Borić D, Draşovean F, Jakucs J, Marić M, Orton D, Pantović I, Schier W, Tasić VL, M, (2016) A Vinča potscape: formal chronological models for the use and development of Vinča ceramics in southeast Europe. Documenta Praehistorica 43:1-60

Yiouni P (2000) Painted pottery from East Macedonia in North Greece: technological analysis of decorative techniques. Documenta Praehistorica $27: 198-214$

Publisher's note Springer Nature remains neutral with regard to jurisdictional claims in published maps and institutional affiliations. 